\title{
Measure Guideline: Evaporative Condensers
}

A. German, B. Dakin, and M. Hoeschele Alliance for Residential Building Innovation (ARBI)

March 2012 


\section{NOTICE}

This report was prepared as an account of work sponsored by an agency of the United States government. Neither the United States government nor any agency thereof, nor any of their employees, subcontractors or affiliated partners makes any warranty, express or implied, or assumes any legal liability or responsibility for the accuracy, completeness, or usefulness of any information, apparatus, product, or process disclosed, or represents that its use would not infringe privately owned rights. Reference herein to any specific commercial product, process, or service by trade name, trademark, manufacturer, or otherwise does not necessarily constitute or imply its endorsement, recommendation, or favoring by the United States government or any agency thereof. The views and opinions of authors expressed herein do not necessarily state or reflect those of the United States government or any agency thereof.

Available electronically at http://www.osti.gov/bridge

Available for a processing fee to U.S. Department of Energy

and its contractors, in paper, from:

U.S. Department of Energy

Office of Scientific and Technical Information

P.O. Box 62

Oak Ridge, TN 37831-0062

phone: 865.576 .8401

fax: 865.576 .5728

email: mailto:reports@adonis.osti.gov

Available for sale to the public, in paper, from:

U.S. Department of Commerce

National Technical Information Service

5285 Port Royal Road

Springfield, VA 22161

phone: 800.553 .6847

fax: 703.605 .6900

email: orders@ntis.fedworld.gov

online ordering: http://www.ntis.gov/ordering.htm 


\title{
Measure Guideline: Evaporative Condensers
}

\author{
Prepared for: \\ Building America \\ Building Technologies Program \\ Office of Energy Efficiency and Renewable Energy \\ U.S. Department of Energy \\ Prepared by: \\ A. German, B. Dakin, M. Hoeschele \\ Alliance for Residential Building Innovation (ARBI) \\ Davis Energy Group, Team Lead \\ 123 C Street \\ Davis, California 95616 \\ NREL Technical Monitor: Michael Gestwick \\ Prepared under Subcontract No. KNDJ-0-40340-00
}

March, 2012 
[This page left blank] 


\section{Contents}

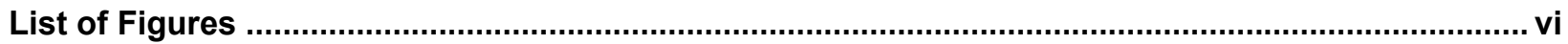

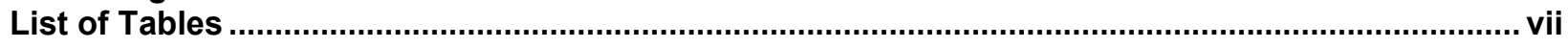

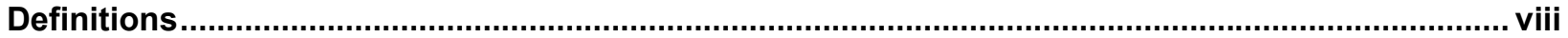

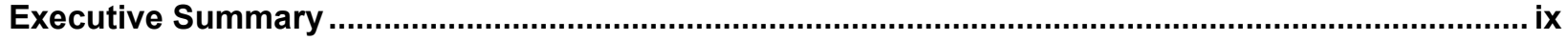

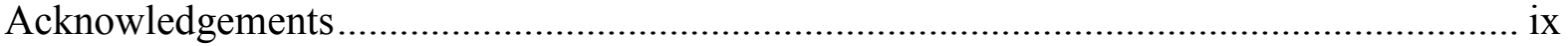

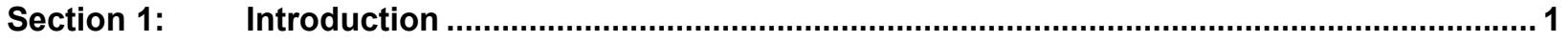

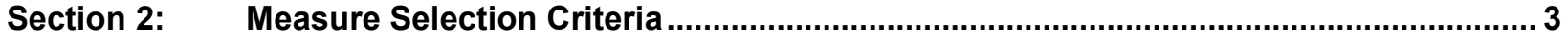

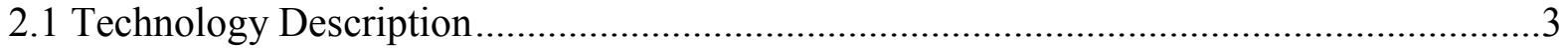

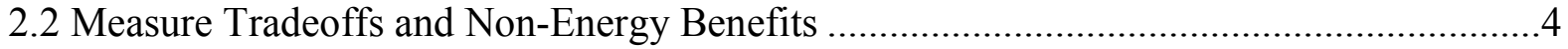

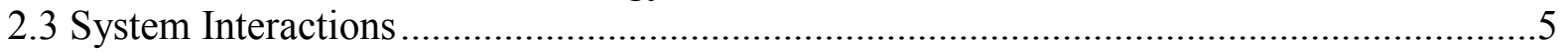

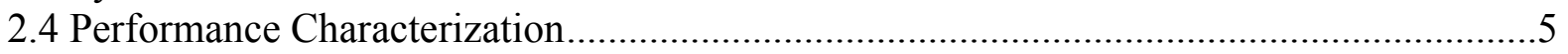

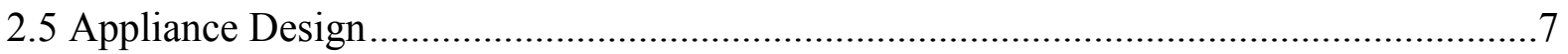

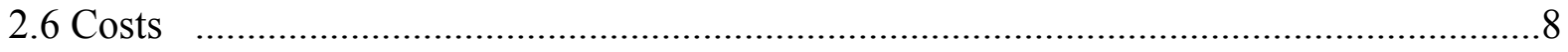

2.7 Energy Savings and Cost Effectiveness.................................................................... 10

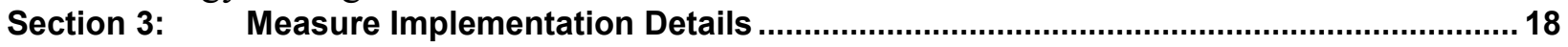

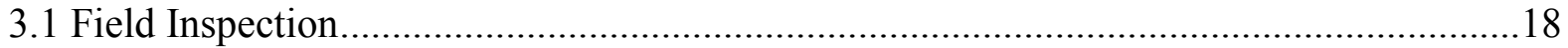

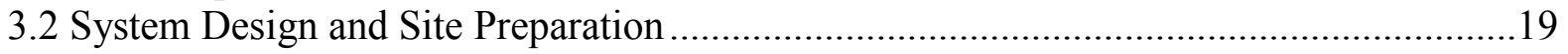

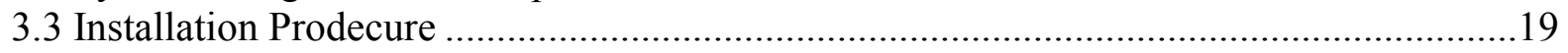

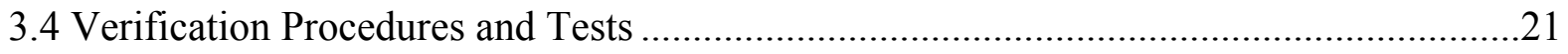

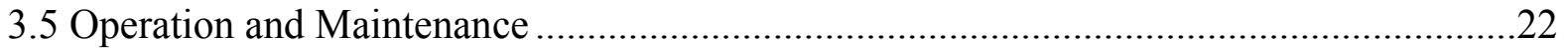

Attachment A: Prescriptive Measure Checklist for Contractors ..................................................... 24

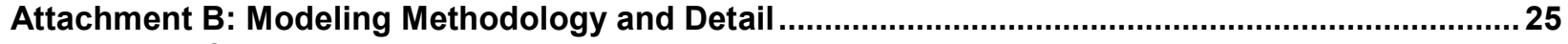

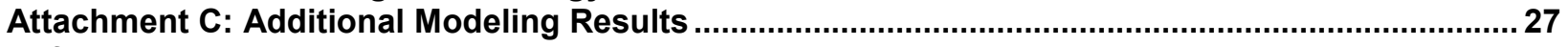

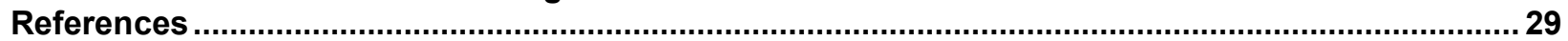




\section{List of Figures}

Figure 1: Evaporative condenser operation schematic.

Figure 2: Performance characterization of air-cooled and evaporative cooled condensers over a range of outdoor dry bulb temperatures.

Figure 3: Example of condenser coil configuration to allow for adequate drainage of liquid refrigerant.

Figure 4: Condenser coil before (left) and after (right) prolonged operation without any water management strategies

Figure 5: Building America and IECC climate zone reference map.................................................. 11

Figure 6: Annual cooling energy comparison of air-cooled and evaporative cooled condensers over a range of rated EER in a hot-dry climate

Figure 7: Full load condenser EER (Btu/wh) (no indoor fan energy) versus both outdoor and entering wet-bulb temperatures $\left(W^{\circ} \mathrm{F}\right)$

Figure 8: Float to adjust water sump level

Figure 9: Gauges connected to operating evaporative condenser to verify correct charge ............ 21

Figure 10: Water sump and pump filter basket during operation

Unless otherwise noted, all figures were created by the ARBI team. 


\section{List of Tables}

Table 1: Annual Cooling Energy Savings Compared to a SEER 13 Air Conditioner ....................... 12

Table 2: Annual Cooling Energy Savings Compared to a SEER 15 Air Conditioner ........................ 12

Table 3: Incremental Cost Justified by Energy Modeling Savings Compared to a SEER 13 Air Conditioner for Various Interest Rate Financing Scenarios

Table 4: Incremental Cost Justified by Energy Modeling Savings Compared to a SEER 15 Air Conditioner for Various Interest Rate Financing Scenarios

Table 5: Minimum Annual Cooling UtilityBill to Justify Evaporative Condensers under Various Payback Scenarios Based on a Mature Market Incremental Cost of \$750 over a SEER 13 Air Conditioner.

Table 6: Minimum Annual Cooling Utility Bill to Justify Evaporative Condensers under Various Payback Scenarios Based on a Mature Market Incremental Cost of \$350 over a SEER 15 Air Conditioner.

Table 7: New Construction Assumptions by Climate Zone ........................................................... 25

Table 8: Existing Home Assumptions by Building Vintage ....................................................... 26

Table 9: Annual Cooling Energy Savings Compared to an Existing Home Circa 1980 with a SEER 13 Air Conditioner

Table 10: Annual Cooling Energy Savings Compared to an Existing Home Circa 1980 with a SEER 15 Air Conditioner.

Table 11: Annual Water Operating Costs for Evaporative Condenser Assuming National Average Water Rates

Table 12: Incremental Cost Justified by Energy Modeling Savings Compared to a SEER 13 Air Conditioner for Various Interest Rate Financing Scenarios - Includes Both Energy Utility Savings and Additional Water Costs.

Table 13: Incremental Cost Justified by Energy Modeling Savings Compared to a SEER 15 Air Conditioner for Various Interest Rate Financing Scenarios - Includes Both Energy Utility Savings and Additional Water Costs....

Unless otherwise noted, all tables were created by the ARBI team. 


\section{Definitions}

$\mathrm{AC}$

ACCA

AFUE

AHRI

ARBI

Btu

CARB

CEC

cfm

DEG

${ }^{\circ} \mathrm{F}$

EC

EER

EIR

HSP

HVAC

$\mathrm{kW}$

$\mathrm{kWh}$

SHGC

SMUD

PG\&E

RECS

SCE

SEER

TXV

W

ZNE
Air conditioner

Air Conditioning Contractors of America

Annual Fuel Utilization Efficiency - Seasonal efficiency for residential gas furnaces

Air-Conditioning, Heating, and Refrigeration Institute

Alliance for Residential Building Innovation

British thermal unit

Consortium for Advanced Residential Buildings

California Energy Commission

Cubic feet per minute

Davis Energy Group

Degrees Fahrenheit

Evaporative condenser

Energy Efficiency Ratio

Electric input ratio

House Simulation Protocols

Heating, ventilation, and air conditioning

Kilowatt

Kilowatt-hour

Solar heat gain coefficient

Sacramento Municipal Utility District

Pacific Gas and Electric Company

Residential Energy Consumption Survey

Southern California Edison

Seasonal Energy Efficiency Ratio

Thermostatic expansion valve

Watt

Zero net energy 


\section{Executive Summary}

The purpose of this measure guideline on evaporative condensers is to provide information on a cost-effective solution for energy and demand savings in homes with cooling loads. This is a prescriptive approach that outlines selection criteria, design and installation procedures, and operation and maintenance best practices. This document has been prepared to provide a process for properly designing, installing, and maintaining evaporative condenser systems as well as understanding the benefits, costs, and tradeoffs. The primary audience for this document includes the following:

- HVAC contractors

- Builders

- Remodelers.

As a secondary audience, homeowners who have a basic understanding of HVAC systems will also benefit from the information contained within.

Evaporative cooling has been used successfully throughout history to provide cooling and is especially effective in hot-dry climates. The use of evaporative processes to improve cooling efficiency is an important vehicle for reducing energy use and peak demand in hot-dry climates. Direct space cooling through evaporative cooling does not provide the same quality of comfort as compressor-based processes in that for most technologies moisture is added rather than removed from the air. While this may be acceptable in dry climates it is not in humid climates where air conditioning is relied upon not only for sensible cooling but for dehumidification. Evaporative condensers utilize the high efficiency of evaporative cooling at the condensing unit, while also providing dehumidification identical to a conventional air conditioning system. Evaporative condensers may play a key role in meeting Building America performance goals in new homes, and also in existing homes that have high loads due to sub-standard wall insulation and windows, that are much more costly to upgrade.

\section{Acknowledgements}

Davis Energy Group would like to acknowledge the United States Department of Energy Building America program and their funding and support of development of this guideline as well as research that informed it. We also thank Western Cooling Efficiency Center at the University of California, Davis for their research and contribution to this measure guideline. In addition, we would like to acknowledge Pacific Gas and Electric, Southern California Edison and the Sacramento Municipal Utility District for their previous research efforts that have contributed to the large body of information on evaporative condensers and have supported product development. 


\section{Section 1: Introduction}

Residential air conditioning has become increasingly common throughout the United States over the past 30 years as comfort demands have increased and market demands have pushed compressor-based cooling into climates not previously seen. Increasingly, air conditioners are being installed in milder, transitional climates to compensate for these increased comfort demands, as well as increased building loads seen from the trend towards larger homes and greater window areas. The 2009 Residential Energy Consumption Survey (RECS) shows that $61 \%$ of residential homes have central air conditioning. This is up significantly from $47 \%$ in 1997 and only $23 \%$ in $1978^{1}$.

Evaporative cooling has been used successfully throughout history to provide cooling and is especially effective in hot-dry climates. The use of evaporative processes to improve cooling efficiency is an important vehicle for reducing energy use and peak demand in hot-dry climates. Direct space cooling through evaporative cooling does not provide the same quality of comfort as compressor-based processes in that for most technologies, moisture is added rather than removed from the air. While this may be acceptable in dry climates, it is not in humid climates where air conditioning is relied upon not only for sensible cooling but for dehumidification. Evaporative condensers (ECs) utilize the efficiency of evaporative cooling to cool entering condenser air at the condensing unit, while also providing dehumidification identical to a conventional air conditioning system. Evaporative condensers may play a key role in meeting Building America performance goals in new homes, and also in existing homes that have high loads due to sub-standard wall insulation and windows, that are much more costly to upgrade.

The purpose of this measure guideline on evaporative condensers is to provide information on a cost-effective solution for energy and demand savings in homes with cooling loads. This document outlines system tradeoffs including a discussion of selection criteria, system performance, energy and cost savings, design and installation procedures, and operation and maintenance best practices. The primary audience for this document includes contractors, builders, and remodelers with certain information also applicable to homeowners.

Previous research has demonstrated the efficiency benefits of evaporative condensers. Davis Energy Group (DEG) has completed simulations and laboratory and field testing of a variety of evaporative condensers. With Building America support, a Freus unit was field tested in the Southern California desert town of Borrego Springs in 2006 and 2007 (Springer et al, 2008). Performance results showed significant energy savings over standard air-cooled condensing equipment. During 2009, DEG worked with Beutler Corporation (manufacturer of the AquaChill evaporative condenser) to assess AquaChill design and performance, and help set up their inhouse test facility. Potential enhancements were identified with the help of a refrigeration engineer and design variations were tested. Condenser coil and other design improvements were incorporated into the "second generation" system and lab testing of this design showed improved performance over the previous version, with a $15 \mathrm{EER}$ rating at AHRI conditions $\left(75^{\circ} \mathrm{F}\right.$ outdoor wet bulb temperature). These results are also summarized in The Consortium of Advanced Residential Buildings' (CARB) Building America 2009 annual report (CARB, 2009). Lab testing of a production AquaChill unit was also completed by Southern California Edison (SCE, 2009)

\footnotetext{
${ }^{1} \mathrm{http}: / /$ www.eia.gov/emeu/consumptionbriefs/recs/actrends/recs_ac_trends.html
} 
and reported an EER of 13.5 at AHRI conditions, but applied actual fan energy use instead of a default value.

In December 1998, Davis Energy Group (DEG, 1998) completed an evaluation of residential evaporative condensers that involved evaluation of two EC designs including: evaluating test data from Pacific Gas \& Electric's (PG\&E) Technical and Ecological Services (TES) laboratory, developing DOE-2 performance curves based on the lab test data, estimating EC savings using DOE-2 and the developed curves, and field testing of ECs. In the summer of 2007, Davis Energy Group evaluated two residential Freus installations for a PG\&E technology evaluation report (DEG, 2008). Monitoring data from the sites were used to develop a performance algorithm using MicroPas hourly loads. Simulation projections suggest $21 \%-33 \%$ annual cooling energy savings and 22\%-35\% coincident peak cooling demand savings in typical Central Valley applications.

During the summer of 2009, the Sacramento Municipal Utility District (SMUD) worked with ADM Associates to complete monitoring and field evaluation of 26 AquaChill units (Keesee et al, 2010). The data was analyzed and compared to usage data for typical residential homes in SMUD territory. Findings from the study include that air conditioning energy use can be reduced by $29 \%$ for a typical single family home in SMUD territory and peak power can be potentially reduced $23 \%$ compared to a typical single family 4 -ton unit.

The improved "second generation" AquaChill was installed and instrumented at an existing, occupied home in Davis, California, in September, 2010, and was monitored through the 2011 summer (ARBI, 2011). Results showed an average measured condenser EER of 17. In 2010, DEG conducted a study for PG\&E to evaluate evaporatively cooled condensers as a potential component of a Zero Net Energy (ZNE) strategy for new and existing homes (DEG, 2010). The results of the study showed that evaporative condensers have significant benefits and can be cost effective in hot-dry climates where cooling energy use is significant. 


\section{Section 2: Measure Selection Criteria}

\subsection{Technology Description}

Evaporative condensers (ECs) operate by rejecting condenser heat to a water sump that is cooled by the evaporation of water. They replace the fin-tube air-cooled condenser coil with a refrigerant-to-water copper heat exchanger that is evaporatively cooled. ECs cool the refrigerant by spraying water on the condenser coils during operation, resulting in lower condensing temperatures, reducing demand, and potentially improving utility load factor because the increased efficiency is most pronounced during peak demand periods that correspond with the hottest days of the summer. The temperatures seen by the refrigerant in the condensing unit more closely follow the outdoor wet bulb temperature than the outdoor dry bulb temperature. This allows for higher operating efficiencies than their high efficiency air-cooled counterparts due to the fact that wet bulb temperatures can be as much as $40^{\circ} \mathrm{F}$ lower than peak summer dry bulb temperatures, especially in dry Southwestern climates.
Evaporative Cooler vs. Evaporative Condenser

An evaporative cooler works by cooling the supply air stream through evaporation of water, which generally results in increased relative humidity inside the home. Evaporative condensers use the same principle but to cool the refrigerant at the outdoor condensing unit by cooling entering condenser air. Since the refrigerant is part of a closed loop this strategy does not result in the addition of moisture into the home.

Earlier EC designs consisted of a conventional air-cooled condenser with evaporative media wrapped around the outside to evaporatively pre-cool the air entering the condensing unit. The

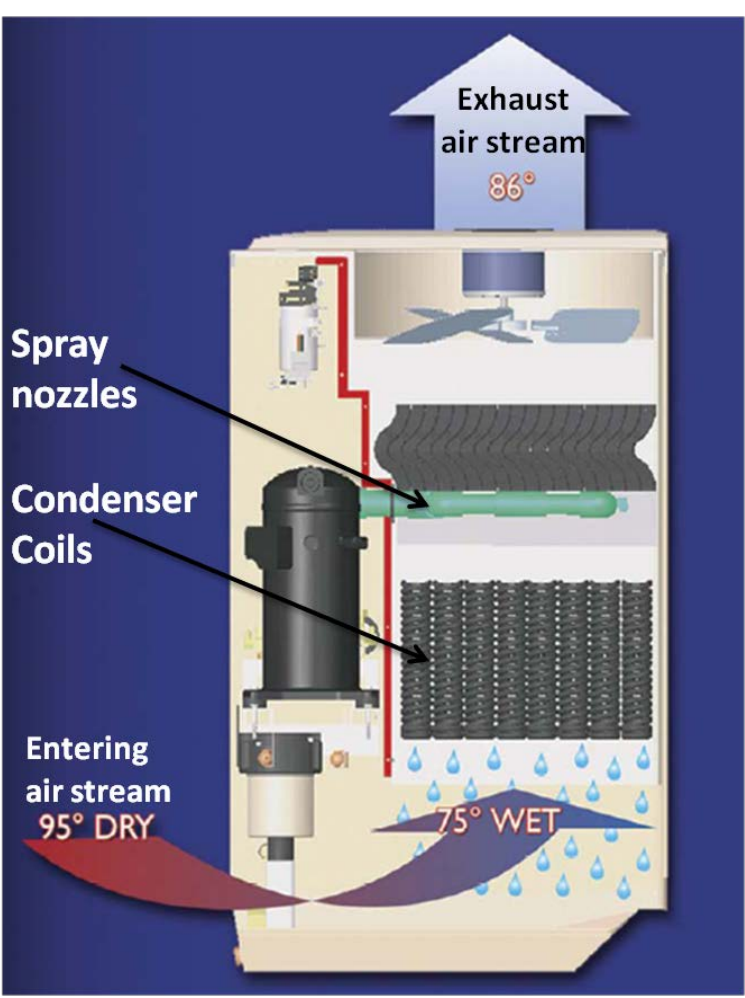

Figure 1: Evaporative condenser operation schematic first true residential evaporative condenser was introduced into the market in 1997 by Bacchus Industries. This design immersed the refrigerant coils in the sump of evaporatively cooled water providing significant performance benefits due to both the improved heat transfer effectiveness and to the impact of lower condensing temperatures. It also eliminated the issue of condenser coil fin degradation associated with moisture drift in the earlier designs.

Modern designs operate by spraying a continuous flow of water on to the refrigerant lines while the condenser inlet air passes up through the water covered refrigerant lines (see Figure 1). Upward-flowing condenser inlet air absorbs moisture from the water spray and becomes cooler, conducting heat away from the tube surfaces in the process. The cooled inlet air continues to absorb moisture as it evaporates the water film on the refrigerant tube surfaces. This evaporation of water results in further cooling of the refrigerant lines.

Evaporative condensers require water to provide the evaporative cooling effect. Water is consumed both by 
evaporation and the replacement of cooling water to avoid excessive mineral build-up in the sump water. This can be accomplished either by periodically purging the sump or through a bleed line where water is continually bled off the high pressure side of the circulating pump during operation.

\subsection{Measure Tradeoffs and Non-Energy Benefits}

The following subsections describe the non-energy benefits and tradeoffs unique to residential evaporative condensers.

\section{Occupant Comfort, Health, and Safety}

Evaporative condensers operate on a similar principle as evaporative coolers, but without the side effects of reduced occupant comfort due to humidification of the airstream. Indoor air quality and perceived comfort are the same as with a conventional air-cooled condenser. Evaporative condensers meet all performance and prescriptive-based safety, health, and building code requirements for use in both new and existing homes.

\section{Legionnaire's Disease}

Evaporative condensers afford an environment that is potentially favorable to the growth of Legionnaires' disease bacteria, or Legionella. Legionella infections have been traced to commercial cooling towers, and it is possible that given the sump water temperatures, Legionella could be present in evaporative condensers. However, the system enclosures and drift eliminators in residential evaporative condensers appear to be effective at eliminating the aerosols which are commonly given off by larger cooling towers. There are no reports of health risks in the literature stemming from the use of these products.

\section{Equipment Maintenance}

Evaporative condensers require more maintenance than air-cooled condensers. If the water is not replaced regularly through a purge cycle or continuous bleed, hardness minerals will build up on the system components, reducing equipment performance, and ultimately leading to potential component failure. The units require semi-annual maintenance at the beginning and the end of each cooling season. At the end of each cooling season, the condensing unit needs to be disconnected, the water supply turned off and the sump drained, leaving the drain plug off during winter. At the beginning of each cooling season, the intake screens and base pan need to be hosed off and cleaned of any debris, the drain plug reinstalled, water valve opened and power restored to the unit.

\section{Water Usage}

Water is consumed through both the evaporation process and through water removed during the purge cycles. Most of the water consumption is due to evaporation and the rate of use is dependent upon outdoor climate conditions, with evaporation rates increasing with hotter and dryer operating conditions (SCE, 2009). Some water districts have sensitivity to the use of evaporative cooling equipment due to the issue of increased water use. The California Energy Commission (CEC) under the Title-24 state energy code requires that evaporative condensers do not use more than 5.0 gallons per ton-hour of capacity at AHRI rating conditions (CEC, 2010). While the current cost of water is sufficiently low as to present no operating cost barriers, increasing water rates and local restrictions on water use could have a negative impact on the 
proliferation of evaporative condensers. However, "purge" or "bleed" water can be used for irrigation and in most cases can be easily routed from the unit to an appropriate use site.

\section{Climate Considerations}

Evaporative condensers offer the greatest benefit in hot-dry climates where cooling loads are high and dry outdoor temperatures allow for higher operating efficiencies than a comparable aircooled condenser under the same condition. While evaporative condensers will provide some performance advantage over air-cooled condensers under humid conditions, they may not offer sufficient savings to justify any additional costs and water usage.

\section{Borrego Springs Field Monitoring}

Under Building America, Davis Energy Group monitored evaporative condenser and aircooled condenser performance in four test homes located in the desert climate of Borrego Springs, California, for 15 months in 2006 and 2007 (Springer et al, 2008). Overall steady state efficiency of the evaporative condenser was almost twice as high as that of the 13 SEER unit (12 EER vs. 7 EER) and about the same as the 21 SEER unit operating in $2^{\text {nd }}$ stage.

\section{Durability and Reliability}

It is difficult to assess long term durability of current evaporative condenser technologies because they have been available in their current form for less than ten years. However, current evaporative condensers have achieved a measure of reliability and durability over the relatively short length of time they have been on the market. DEG installed a Freus unit to provide cooling for their offices in 2006 and has intentionally avoided periodic maintenance to determine the consequences. The only maintenance that has been required to keep it operating is cleaning leaves and debris from the strainer around the pump. Another Freus unit was installed on a home in Borrego Springs as part of an earlier Building America study (Springer et al, 2008). There have been no reports of failure from the owner since it was installed in 2007. Pump failure has been an issue in certain applications. Water pumps may require more frequent replacement than other components.

\subsection{System Interactions}

Often, the most cost-effective energy-savings measures that can be implemented are those that reduce the cooling and heating loads. Savings can be enhanced through a whole-building performance-based approach of optimizing building orientation, and building envelope design that includes proper window management through the use of high performance windows and reducing glazing area, high insulation levels, and good building construction practices that result in reducing building heating and cooling loads.

Proper design and commissioning of other components within the HVAC system is also crucial for optimal system performance. Airflow and the ductwork should be sized according to the building and system requirements. Undersized ductwork and returns along with high pressure drop air filters will increase system static pressure resulting in lower airflows across the cooling coil and subsequently reduced cooling capacity with PSC fan systems, or increased fan energy with ECM fan systems, causing reduced system performance and comfort.

\subsection{Performance Characterization}

The performance of air-cooled vapor compression equipment degrades with increasing outdoor temperatures. As refrigerant condensing temperatures rise with increasing condenser inlet air 
temperatures, electrical demands for air-cooled equipment increase and cooling capacity drops resulting in lower equipment efficiencies. Typically, air-cooled equipment condenses at temperatures $15^{\circ} \mathrm{F}-25^{\circ} \mathrm{F}$ higher than the outdoor dry bulb temperature. However, evaporative condenser condensing temperatures are based on the coincident outdoor wet bulb temperature.

With evaporative condensers, the refrigerant condensing temperature is based on the coincident outdoor wet bulb temperature at any outdoor dry bulb condition. During peak cooling periods in hot dry climates, this is $20^{\circ} \mathrm{F}$ to $40^{\circ} \mathrm{F}$ lower than the condensing temperatures seen by air-cooled condensers. The lower condensing temperature allows for more efficient compressor operation and increased capacity. Since evaporative condenser efficiency is tied to outdoor wet bulb temperature, both capacity and efficiency degradation are lower as outdoor temperature increases. Both the cooling capacity and efficiency of evaporative condensers are relatively constant in dry climates because wet bulb temperatures vary much less than dry bulb temperatures. This characteristic promises a performance advantage over air-cooled equipment in hot-dry climates, and allows for cooling system downsizing in many applications.

Figure 2 shows air conditioner efficiency over a range of outdoor dry bulb temperatures for a hot-dry climate assuming AHRI rating conditions ${ }^{2}$. The AHRI rated efficiency for the Beutler AquaChill of 14.7 EER was used for this comparison. It can be seen that the evaporative condenser performs better than a similarly rated air-cooled condenser at dry bulb temperatures above $95^{\circ} \mathrm{F}$ (the temperature at which the AHRI EER rating test is conducted), which usually coincides with times of peak load during the afternoon. It is also the case that dry climates are often dryer than the AHRI assumptions which would move the evaporative condenser curve up resulting in high efficiencies at even higher temperatures. A typical highefficiency air-cooled unit is rated at 12.5 EER and under most

\section{EER vs. SEER}

Similar to air-cooled condensers, evaporative condensers are rated according to EER which is tested at outdoor conditions of $95^{\circ} \mathrm{F}$ dry bulb and $75^{\circ} \mathrm{F}$ wet bulb. There is currently no official AHRI SEER testing procedure for evaporative condensers. California's Title-24 code uses two EER ratings, EERa and EERb, to calculate the seasonal efficiency used for modeling purposes. EERa is the AHRI listed EER. $\mathrm{EERb}$ is tested at conditions similar to those used in the SEER test for aircooled condensers, $82^{\circ} \mathrm{F} / 65^{\circ} \mathrm{F}$ outdoor dry bulb and web bulb, respectively, and is required to be tested and published by the manufacturer according to AHRI guidelines. cooling operating conditions $\left(>80^{\circ} \mathrm{F}\right)$, the evaporative condenser operates more efficiently. This graph is based on performance curves of normalized EIR (electric input ratio) and capacity as a function of entering wetbulb and outdoor drybulb as developed for the DOE2.2 energy model. The BEopt v1.1 default curves for a SEER 13 residential air conditioner were used for the three air-cooled units and the eQUEST default curve for evaporatively cooled condensers (EvapCond-EIR-fEWB andOWB) was used for the evaporative condenser.

\footnotetext{
${ }^{2}$ Assumes constant entering wet bulb temperature of $67^{\circ} \mathrm{F}$ and fan output of $400 \mathrm{cfm} / \mathrm{watt}$ at $0.365 \mathrm{~W} / \mathrm{cfm}$ based on AHRI EER test rating conditions and constant humidity ratio of $0.14 \mathrm{lb}$ water $/ \mathrm{lb}$ dry air.
} 


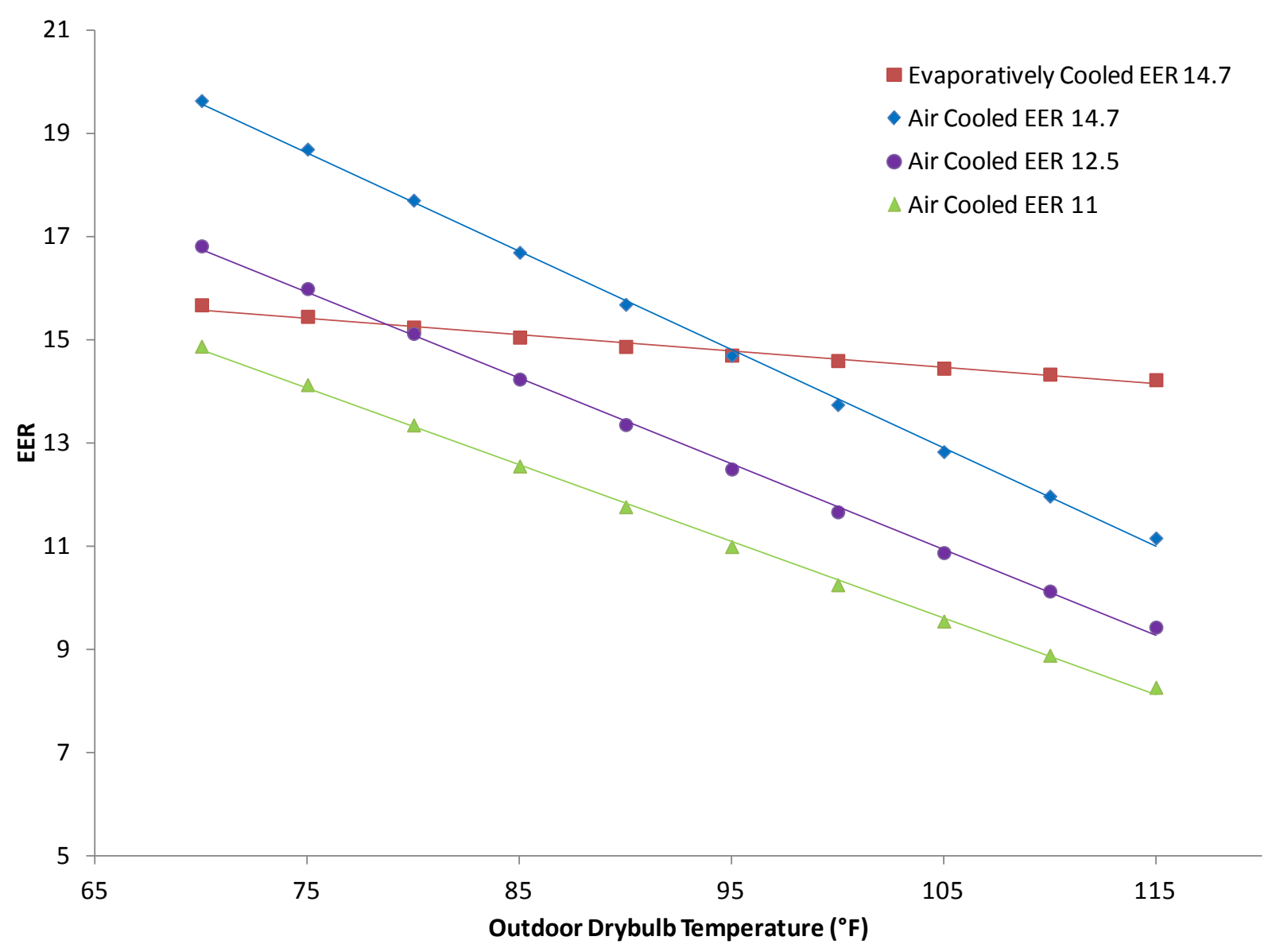

Figure 2: Performance characterization of air-cooled and evaporative-cooled condensers over a range of outdoor dry bulb temperatures

\subsection{Appliance Design}

Evaporative condenser coils are typically configured in a horizontal orientation to increase surface area for contact with the evaporating water. However, this can cause problems with proper liquid refrigerant drainage during operation. The condenser coil should be configured in such a way that it has maximum surface area on the horizontal plane and a slight downward slope to the coils. Figure 3 shows a method of this by coiling the refrigerant tubes in a sort of "inverted beehive" to facilitate drainage.

Build-up of mineral deposits on the condenser coils, in the water sump and on the water system components can be a concern, especially in areas with hard water or water with high levels of dissolved solids. The use of wide spray nozzles reduces the risk of clogging, and the use of sacrificial anodes enhances the life of the other components. These anodes may periodically need to be replaced,

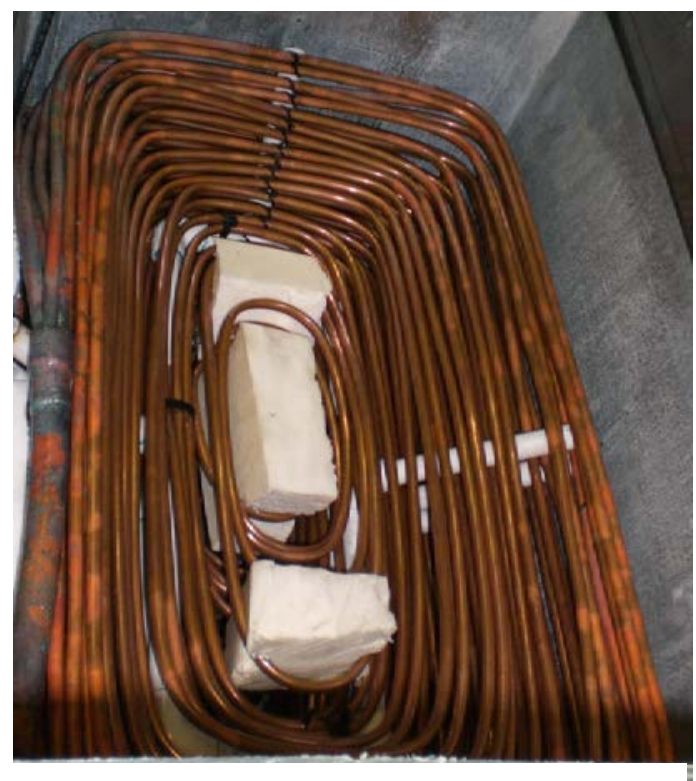

Figure 3: Example of condenser coil configuration to allow for adequate drainage of liquid refrigerant 
depending on water conditions. Proper flushing of water in the water sump is also important. Periodic purge or a continuous bleed are both acceptable strategies. Systems that use a purge strategy must incorporate a second pump which results in additional cost and electricity use.

Due to the constant exposure to water, it is important to isolate the compressor and controls from water spray. Plastic, fiberglass, stainless, or galvanized materials with corrosion resistance should be used in construction.

Safety switches should be installed that turn off the system and initiate a service call in the case of low water levels in the sump. Many systems use a basket-type filter for the water circulation pump. In these cases, the low limit sensor should be installed inside the basket to adequately measure the water levels adjacent to the pump. In the case of extreme clogging of the filter basket, water levels may differ between inside and outside the basket.

\subsection{Costs}

Currently, evaporative condensers are only available through select manufacturers and are produced at very low volumes resulting in relatively high incremental costs. According to conversations with manufacturers, assuming volume pricing there are two system components that represent an additional cost over an air-cooled condenser. One is the water system including the pump and spray device. The other is the corrosion-resistant housing, typically either plastic or fiberglass. These materials are more expensive than standard painted sheet metal and often require a more expensive manufacturing process such as injection molding. Assuming volume production similar to that of air-cooled condensers, manufacturers predict a $30 \%$ system price increase over a high efficiency (SEER 15) air-cooled unit, or roughly \$350. Estimated mature market incremental cost over a SEER 13 unit is $\$ 750$. Currently, costs are significantly higher with incremental equipment costs to the homeowner over a SEER 15 condensing unit between $\$ 1,000$ and $\$ 1,350$. The relative performance of systems that these costs are based on is representative of the 14.7 EER evaporative condenser and the 12.5 EER air-cooled condenser in Figure 2. Incremental costs may be reduced in some cases by equipment downsizing by $1 / 2$ ton due to the reduced capacity degradation of evaporative condensers at high outdoor air design conditions.

Labor costs are assumed to be similar. While additional plumbing is required during installation, it is minimal and contractors who are familiar with evaporative condenser installations do not typically charge for additional labor. Maintenance costs are negligible when maintenance is performed by the homeowner. Homeowners may elect to enter into a maintenance contract with the HVAC contractor. This typically includes semi-annual maintenance with costs around $\$ 175$ annually.

Most high efficiency evaporative condensers require R-410A refrigerant and a thermostatic expansion valve (TXV) installed at the evaporator coil. Replacement costs depend on whether these components are present in the existing unit. The price estimates presented above do not include any additional costs associated with the addition of a TXV or change-out of an evaporator coil. If a TXV is necessary, additional costs are typically around $\$ 150$. There may also be additional labor costs associated with plumbing water source and drain lines to the condenser location. 
Evaporative condensers consume water both through the evaporation process and through replacement of cooling water to keep mineral content down. Water consumption rates are highly dependent on local climate conditions and have been seen to vary quite a bit based on prior studies of both field and laboratory testing, with a range between 1.3 to 3.5 gallons per ton-hr (DEG, 2008; Keesee et al, 2010; SCE, 2009). Water rates across the country also vary drastically; average rates in 2009 were $\$ 3.90$ per 1,000 gallons (Global Water Intelligence, 2009). ${ }^{3}$ Assuming 400 hours of summer operation on a 3 -ton system in a hot-dry climate ${ }^{4}$ and an average consumption rate of 2.5 gallons per ton-hr, this results in an average annual cost of about $\$ 12.00$ for evaporative condenser water usage.

\section{Supporting Research}

The UC Davis Western Cooling Efficiency Center is currently conducting accelerated aging tests on an AquaChill evaporative condenser by operating the unit continuously without removing any dissolved solids (no pump down or bleed off). This testing assesses the effect of mineral deposits on performance degradation. Makeup water is supplied to maintain proper sump level. The water supply is Davis, California, city water which is very hard (303 $\mathrm{ppm})$ and high in total dissolved solids $(520 \mathrm{ppm})$. Currently the unit has been operating for a 6-month period with over 1,700 hours of operation (60 minutes on followed by 30 minutes off). This is the equivalent of four to six summers of operation in a hot-dry climate (based on 300-400 total annual hours of operation identified from monitoring studies). Significant scaling of the condenser coils (see pictures below), water sump, pump, and spray nozzles has been observed; however, condenser performance degradation has only been on the order of $20 \%$. Results are preliminary and will be reported on in 2012 under a project funded by Southern California Edison.

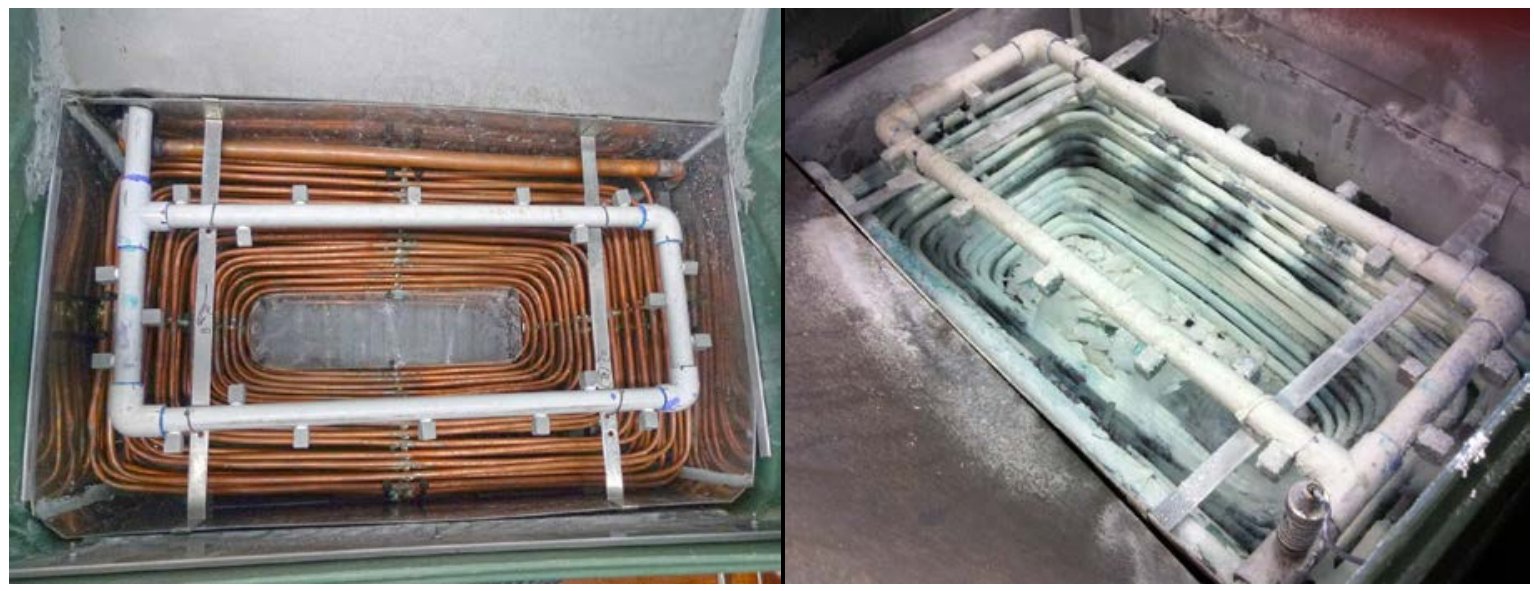

Figure 4: Condenser coil before (left) and after (right) prolonged operation without any water management strategies

\footnotetext{
${ }^{3}$ Global Water Intelligence, Vol 10, Issue 9 (September 2009).

http://www.globalwaterintel.com/archive/10/9/market-insight/no-let-pressure-water-tariffs.html

${ }^{4}$ This is a conservative estimate based on monitoring in the hot-dry climate of Davis, California, on an existing home over a relatively mild summer. A total of 316 operating hours were monitored.
} 


\subsection{Energy Savings and Cost Effectiveness Energy Savings}

An evaluation of energy savings was completed using BEopt v1.1 which has the capability of modeling evaporatively cooled condensers. The AHRI rated efficiency for the Beutler AquaChill of 14.7 EER was used for modeling purposes. Recent monitoring in hot-dry climates has shown operational efficiencies above this with an estimated EER at rated conditions of 16.2. There are effectively two base cases against which an evaporative condenser may be compared. One is a SEER 13, EER 11 air-cooled condenser. SEER 13 is the minimum efficiency for air conditioners according to federal appliance standards. The other is a high efficiency air-cooled condenser, which are increasingly installed throughout the country, especially in areas where residential energy codes are stricter. A commonly installed high efficiency air conditioner has efficiency ratings of SEER 15 and EER 12.5. Table 1 and Table 2 show example cooling energy and demand savings compared to a SEER 13 and a SEER 15 base case, respectively. Savings are representative of new construction assuming a $2,400 \mathrm{ft}^{2}$ house built to Building America Benchmark specifications. Construction assumptions in the model are based on the House Simulation Protocols (Hendron et al, 2010). See Attachment B for a detailed account of the modeling assumptions. Savings percentages are similar for existing homes since the assumption is that air conditioner replacement would occur when the air conditioner reaches the end of its useful life and the base case effectively becomes the unit that would be installed in the absence of an evaporative condenser option. However, absolute annual $\mathrm{kWh}$ savings would be expected to increase for existing homes. Utility dollar savings include savings from the reduction of electricity only and do not include water costs. See Attachment $\mathrm{C}$ for modeling results for existing homes and for analysis that includes water costs.

Specific climates were selected for evaluation to cover the major climate regions nationally. Figure 5 shows nationally where both the Building America and IECC climate zones are located. 

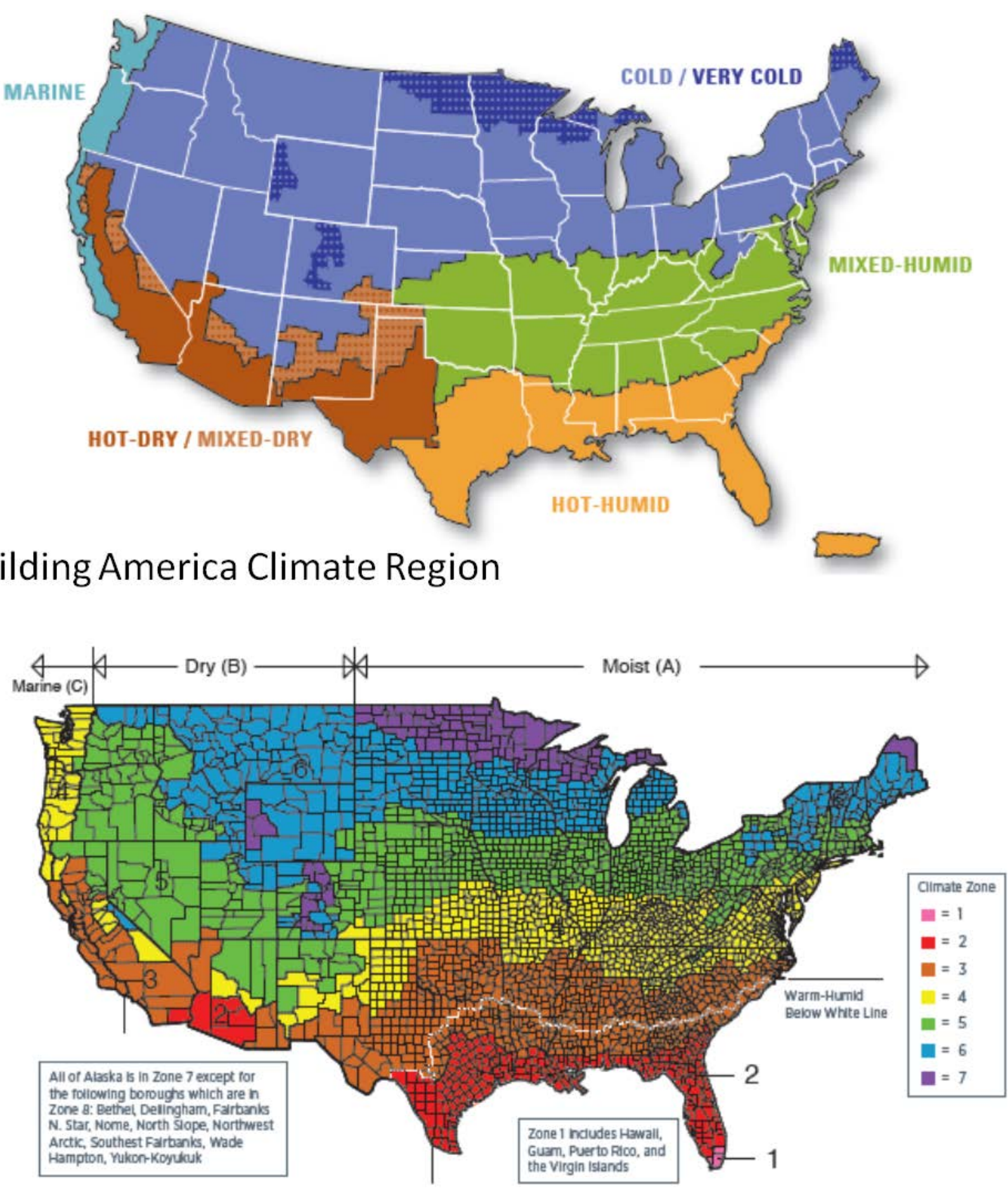

\section{IECC Climate Zone}

Figure 5: Building America and IECC climate zone reference map 
Savings are most significant in hot climates (hot-dry, hot-humid, and mixed-humid) with percent cooling savings at $17 \%$ in humid climates and $27 \%$ in dry climates compared to a SEER 13 unit. While percent savings are still high for cold and marine climates, the reduced cooling load results in relatively small annual kWh savings. The peak demand benefits are substantial, which is especially valuable for summer-peaking electric utilities. Compared to SEER 13 base case, peak load is reduced by over $1 \mathrm{~kW}(>27 \%)$ for both the hot-dry and hot-humid climates. These savings values are reduced between $40 \%$ and $70 \%$ when compared to a SEER 15 air conditioner. While modeling does show decent improvement in humid climates, field studies are necessary to quantify any benefits under humid conditions. The $17 \%$ savings are primarily due to the higher EER over the air-cooled base case. In humid climates it would be more beneficial to invest in an air-cooled unit with higher EER and SEER ratings than the high efficiency base case used in this model instead of an evaporative condenser.

Proper maintenance is important to ensure continued savings over time. Savings may be reduced if maintenance is neglected by the development of water scale on the condenser coils, water nozzles or other components in areas with hard water or water with high levels of dissolved solids.

Table 1: Annual Cooling Energy Savings Compared to a SEER 13 Air Conditioner

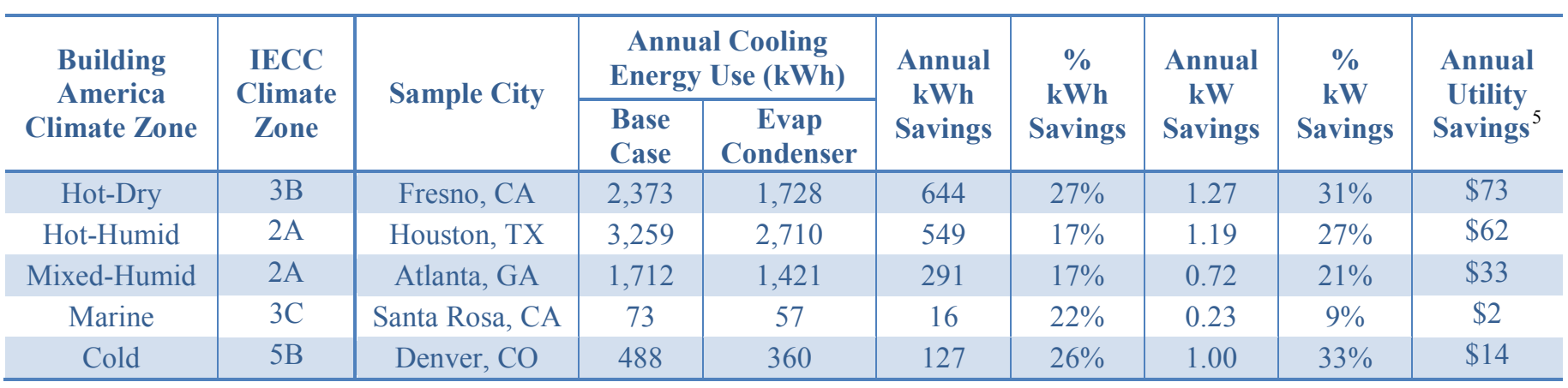

Table 2: Annual Cooling Energy Savings Compared to a SEER 15 Air Conditioner

\begin{tabular}{|c|c|c|c|c|c|c|c|c|c|}
\hline \multirow{2}{*}{$\begin{array}{c}\text { Building } \\
\text { America } \\
\text { Climate Zone }\end{array}$} & \multirow{2}{*}{$\begin{array}{c}\text { IECC } \\
\text { Climate } \\
\text { Zone }\end{array}$} & \multirow{2}{*}{ Sample City } & \multicolumn{2}{|c|}{$\begin{array}{c}\text { Annual Cooling } \\
\text { Energy Use (kWh) }\end{array}$} & \multirow{2}{*}{$\begin{array}{c}\text { Annual } \\
\text { kWh } \\
\text { Savings }\end{array}$} & \multirow{2}{*}{$\begin{array}{c}\% \\
\text { kWh } \\
\text { Savings }\end{array}$} & \multirow{2}{*}{$\begin{array}{c}\text { Annual } \\
\text { kW } \\
\text { Savings }\end{array}$} & \multirow{2}{*}{$\begin{array}{c}\% \\
\text { kW } \\
\text { Savings }\end{array}$} & \multirow{2}{*}{$\begin{array}{c}\text { Annual } \\
\text { Utility } \\
\text { Savings }\end{array}$} \\
\hline & & & $\begin{array}{l}\text { Base } \\
\text { Case }\end{array}$ & $\begin{array}{c}\text { Evap } \\
\text { Condenser }\end{array}$ & & & & & \\
\hline Hot-Dry & $3 \mathrm{~B}$ & Fresno, CA & 2,094 & 1,728 & 366 & $17 \%$ & 0.87 & $24 \%$ & $\$ 41$ \\
\hline Hot-Humid & $2 \mathrm{~A}$ & Houston, TX & 2,874 & 2,710 & 164 & $6 \%$ & 0.75 & $19 \%$ & $\$ 18$ \\
\hline Mixed-Humid & $2 \mathrm{~A}$ & Atlanta, GA & 1,511 & 1,421 & 91 & $6 \%$ & 0.40 & $13 \%$ & $\$ 10$ \\
\hline Marine & $3 \mathrm{C}$ & Santa Rosa, CA & 64 & 57 & 7 & $11 \%$ & 0.03 & $1 \%$ & $\$ 1$ \\
\hline Cold & $5 \mathrm{~B}$ & Denver, $\mathrm{CO}$ & 432 & 360 & 71 & $17 \%$ & 0.73 & $27 \%$ & $\$ 8$ \\
\hline
\end{tabular}

Figure 6 shows a comparison of cooling energy use generated through BEopt modeling in a hotdry climate for an air-cooled condenser and evaporative condenser relative to rated EER. The

\footnotetext{
5 National average utility rate of $\$ 0.1126 / \mathrm{kWh}$

${ }^{6}$ National average utility rate of $\$ 0.1126 / \mathrm{kWh}$
} 
single data point for the evaporative condenser is representative of the 14.7 EER based on the AquaChill. Considering energy use only, an evaporative condenser rated at 14.7 EER will perform better than an air-cooled condenser that is rated 15 EER or below. As rated EER increases, the difference between the two system types becomes less disparate until they cross around 16 EER.

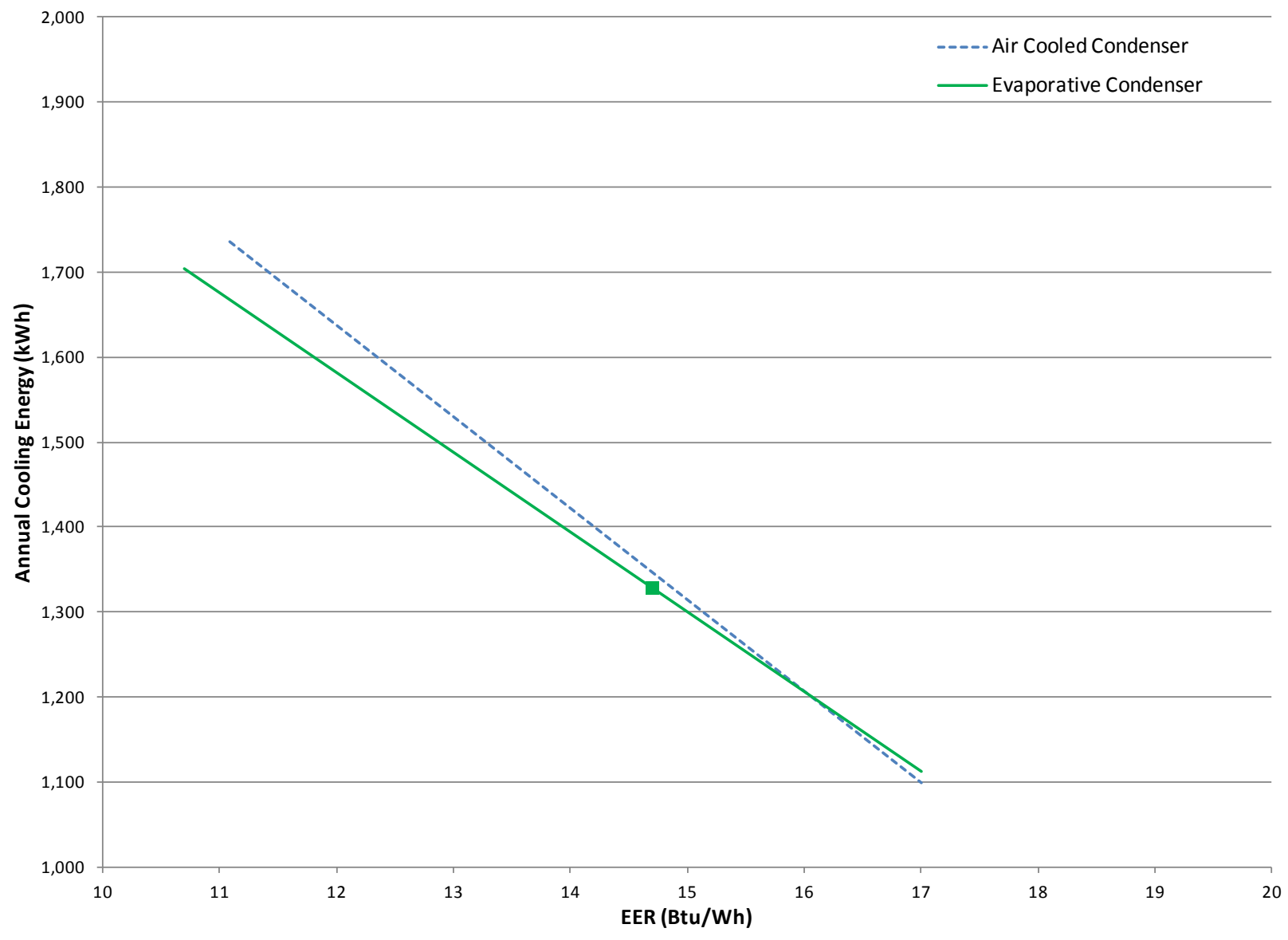

Figure 6: Annual cooling energy comparison of air-cooled and evaporative cooled condensers over a range of rated EER in a hot-dry climate

Savings and cost effectiveness ultimately depends on the building cooling load and air conditioner energy use within the home. Analysis using BEopt was conducted to identify the sensitivity of savings to building cooling load. Within a given climate zone, percent cooling savings is relatively consistent across both existing and new buildings with various building characteristics and cooling loads.

\section{Cost Effectiveness - New Construction}

Incremental costs for energy efficiency in new construction are typically passed on to the homeowner and financed through the home mortgage. Assuming a 30-year mortgage term Table 3 and Table 4 show the incremental cost over the SEER 13 and SEER 15 base cases, respectively, that would result in a positive annual cash flow to the homeowner based on utility electricity savings and mortgage payments. 
Evaporative condensers are recommended in hot-dry climates where the advantage over aircooled condensers is most significant. Assuming mature market incremental costs of $\$ 750$ and $\$ 350$ over a SEER 13 and SEER 15 air conditioner, respectively, it can be seen that the evaporative condenser is cost effective under all reasonable financing scenarios in a hot-dry climate. Cost effectiveness in hot-humid climates also looks favorable; however, further field testing of this technology in humid climates is necessary to better qualify modeling results. Cost effectiveness is reduced in milder climates where lower cooling loads diminish the savings potential. Areas with higher electricity rates or houses with higher cooling loads will benefit from increased cost effectiveness.

Given the high variability of water rates, costs associated with water use are not included in this analysis. A similar analysis that includes water costs based on national averages is available in Attachment C. Additional maintenance costs have also not been included. When the homeowner signs a maintenance contract it assumes this replaces a similar contract for the base case air conditioner. While there may be an incremental cost above that for an air-cooled unit, this is not expected to be significant.

Table 3: Incremental Cost Justified by Energy Modeling Savings Compared to a SEER 13 Air Conditioner for Various Interest Rate Financing Scenarios

\begin{tabular}{c|c|c|c|c|c}
\hline Climate Zone & $\mathbf{3 \%}$ & $\mathbf{4 \%}$ & $\mathbf{5 \%}$ & $\mathbf{6 \%}$ & $\mathbf{7 \%}$ \\
\hline Hot-Dry & $\$ 1,434$ & $\$ 1,266$ & $\$ 1,126$ & $\$ 1,008$ & $\$ 909$ \\
\hline Hot-Humid & $\$ 1,222$ & $\$ 1,079$ & $\$ 960$ & $\$ 859$ & $\$ 774$ \\
\hline Mixed-Humid & $\$ 648$ & $\$ 572$ & $\$ 509$ & $\$ 456$ & $\$ 411$ \\
Marine & $\$ 36$ & $\$ 32$ & $\$ 28$ & $\$ 25$ & $\$ 23$ \\
\hline Cold & $\$ 283$ & $\$ 250$ & $\$ 223$ & $\$ 199$ & $\$ 180$ \\
\hline
\end{tabular}

Table 4: Incremental Cost Justified by Energy Modeling Savings Compared to a SEER 15 Air Conditioner for Various Interest Rate Financing Scenarios

\begin{tabular}{c|c|c|c|c|c}
\hline Climate Zone & $\mathbf{3 \%}$ & $\mathbf{4 \%}$ & $\mathbf{5 \%}$ & $\mathbf{6 \%}$ & $\mathbf{7 \%}$ \\
\hline Hot-Dry & $\$ 814$ & $\$ 719$ & $\$ 640$ & $\$ 573$ & $\$ 516$ \\
\hline Hot-Humid & $\$ 365$ & $\$ 322$ & $\$ 287$ & $\$ 257$ & $\$ 231$ \\
Mixed-Humid & $\$ 202$ & $\$ 178$ & $\$ 158$ & $\$ 142$ & $\$ 128$ \\
Marine & $\$ 16$ & $\$ 14$ & $\$ 12$ & $\$ 11$ & $\$ 10$ \\
\hline Cold & $\$ 159$ & $\$ 140$ & $\$ 125$ & $\$ 112$ & $\$ 101$ \\
\hline
\end{tabular}


Cost Effectiveness - Retrofit

Financing scenarios are more variable in retrofit applications than in new construction. The homeowner may pay for the upgrade out of pocket or he may finance it through a variety of mechanisms including a second mortgage, low interest energy upgrade loans, or high interest credit cards. Cost effectiveness will depend on interest rates, inflation, and utility rate escalation. Additional modeling was conducted in BEopt to estimate typical energy use for an old air conditioner in an existing home (see Attachments B and C). Modeling inputs assumed an existing air conditioner that has reached the end of its useful life with a degraded operating EER of 8. Due to age and maintenance neglect, many existing air conditioners operate at efficiencies much lower than this. Table 5 and Table 6 shows the minimum annual cooling utility bill for an existing home that justifies the incremental cost of an evaporative condenser for three payback term scenarios over a SEER 13 and SEER 15 air conditioner, respectively. Assumptions include average percent cooling savings ${ }^{7}$ and a mature market cost of $\$ 750$ over a SEER 13 base case and $\$ 350$ over a SEER 15 base case. The cost effectiveness of evaporative condensers improves as cooling energy use increases. Therefore, homes with cooling utility bills larger than those in the tables with benefit from a quicker payback period. In dry climates, because of the minimal mature market cost increase for the evaporative condenser above a SEER 15 air-cooled unit, the cost effectiveness is better compared to the SEER 15 than the SEER 13.

Table 5: Minimum Annual Cooling Utility Bill to Justify Evaporative Condensers under Various Payback Scenarios Based on a Mature Market Incremental Cost of $\$ 750$ over a SEER 13 Air Conditioner

\begin{tabular}{c|c|c|c}
\hline Climate Zone & $\begin{array}{c}\text { 5-year } \\
\text { payback }\end{array}$ & $\begin{array}{c}\text { 10-year } \\
\text { payback }\end{array}$ & $\begin{array}{c}\text { 15-year } \\
\text { payback }\end{array}$ \\
\hline Hot-Dry & $\$ 820$ & $\$ 410$ & $\$ 270$ \\
Hot-Humid & $\$ 1,430$ & $\$ 720$ & $\$ 480$ \\
Mixed-Humid & $\$ 1,330$ & $\$ 670$ & $\$ 440$ \\
Marine & $\$ 1,140$ & $\$ 570$ & $\$ 380$ \\
Cold & $\$ 780$ & $\$ 390$ & $\$ 260$ \\
\hline
\end{tabular}

Table 6: Minimum Annual Cooling Utility Bill to Justify Evaporative Condensers under Various Payback Scenarios Based on a Mature Market Incremental Cost of \$350 over a SEER 15 Air Conditioner

\begin{tabular}{c|c|c|c}
\hline Climate Zone & $\begin{array}{c}\text { 5-year } \\
\text { payback }\end{array}$ & $\begin{array}{c}\text { 10-year } \\
\text { payback }\end{array}$ & $\begin{array}{c}\text { 15-year } \\
\text { payback }\end{array}$ \\
\hline Hot-Dry & $\$ 670$ & $\$ 340$ & $\$ 220$ \\
Hot-Humid & $\$ 2,740$ & $\$ 1,370$ & $\$ 910$ \\
Mixed-Humid & $\$ 2,120$ & $\$ 1,060$ & $\$ 710$ \\
Marine & $\$ 1,310$ & $\$ 650$ & $\$ 440$ \\
Cold & $\$ 620$ & $\$ 310$ & $\$ 210$ \\
\hline
\end{tabular}

Incremental costs for evaporative condensers will vary based on many factors, especially in retrofit applications where site factors will affect the implementation costs. Equipment make and

\footnotetext{
${ }^{7} 26 \%$ and $16 \%$ cooling energy use savings were used for the SEER 13 and SEER 15 base cases, respectively. These values reflect average percent savings based on results from modeling of several different building types.
} 
model, product pricing through distribution channels, contractor familiarity with the technology, changes in production volume, local incentives, and site factors (existing conditions, proximity to water plumbing, etc) are a few of the factors that will influence final project costs. It is highly recommended that current bids along with local utility rates are used in lieu of the default costs, if possible.

Annual utility savings, annual water cost, and simple payback in years can be calculated according to the following equations. Annual cooling electricity use can be estimated by looking at monthly utility bills. Subtract average electricity usage $(\mathrm{kWh})$ in the winter months from average use in the summer months to determine the portion of the bill that can be attributed to air conditioning. If there are other highly seasonal electrical loads, such as electric heating or a pool pump, this methodology will not be accurate. Percent cooling kWh savings can be estimated from values in column 6 of Table 1 or Table 2 depending on the climate zone and base case to be evaluated. Fold_AC is a factor which represents the reduction in energy usage between an existing 8 EER air conditioner and the base case. For evaluating savings compared to a SEER 13 base case, use 0.72 for $\mathrm{F}_{\text {Old } \_A C}$ and for the SEER 15 base case

\section{SMUD Field Testing}

During the summer of 2009, SMUD worked with ADM Associates to complete monitoring and field evaluation of 26 AquaChill evaporative condenser units (Keesee et al, 2010). Their findings concluded that cooling energy use could be reduced in a hot-dry climate by $29 \%$ and peak load by $23 \%$ (4-ton unit) for a typical single family home. use 0.44 . These three values along with the local electricity rate $(\$ / \mathrm{kWh})$ can be used in Equation 1 to estimate annual utility savings. Use Equation 2 to calculate annual water costs associated with operating the evaporative condenser. Annual savings and water costs and the incremental cost are then plugged into Equation 3 to calculate an estimated simple payback. If incentives are available subtract those from the incremental cost before calculating payback.

\section{Equation 1}

Annual Utility Savings

$$
=\text { Annual Cooling Energy Use } * F_{\text {Old_AC }} * \frac{\% \mathrm{kWh} \text { Savings }}{100} * \text { Local Utility Rate }(\$ / \mathrm{kWh})
$$

\section{Equation 2}

Annual Water Costs

$$
\begin{aligned}
& =\text { Annual Cooling Energy Use * } F_{\text {Old_AC }} *\left(1-\frac{\% \mathrm{kWh} \text { Savings }}{100}\right) * 1.3(\text { ton } \cdot \mathrm{hr} / \mathrm{kWh}) * \\
& 2.5 \text { (gallon / ton } \cdot \mathrm{hr}) * \text { Local Water Rate }(\$ / \text { gallon })
\end{aligned}
$$

Equation 3

$$
\text { Payback (yrs) }=\frac{\text { Incremental Cost - Incentives }}{\text { Annual Utility Savings - Annual Water Costs }}
$$




\section{Supporting Research}

A second generation AquaChill was installed in an existing home in 2010 and detailed monitoring was conducted throughout the 2011 cooling season (ARBI, 2011). Average operating efficiency of the unit has been 12.6 EER. The 12.6 EER includes monitored fan energy of an old PSC motor operating in existing ducts at high static pressures. Average condenser efficiency (shown in Figure 7 below) without fan energy is roughly 17 EER. Efficiency and system capacity appear to be most sensitive to changes in indoor conditions (Entering WB) and do not appear to vary much with outdoor wet bulb. Linear regression analysis was used to estimate the condenser only EER at rated conditions $\left(75^{\circ} \mathrm{F}\right.$ outdoor wet bulb and $67^{\circ} \mathrm{F}$ entering wet bulb) at an EER of 20.2. Building in standard AHRI assumptions for fan energy $(0.365 \mathrm{~W} / \mathrm{cfm}$ and $400 \mathrm{cfm} / \mathrm{ton})$, system EER was calculated at 16.2.

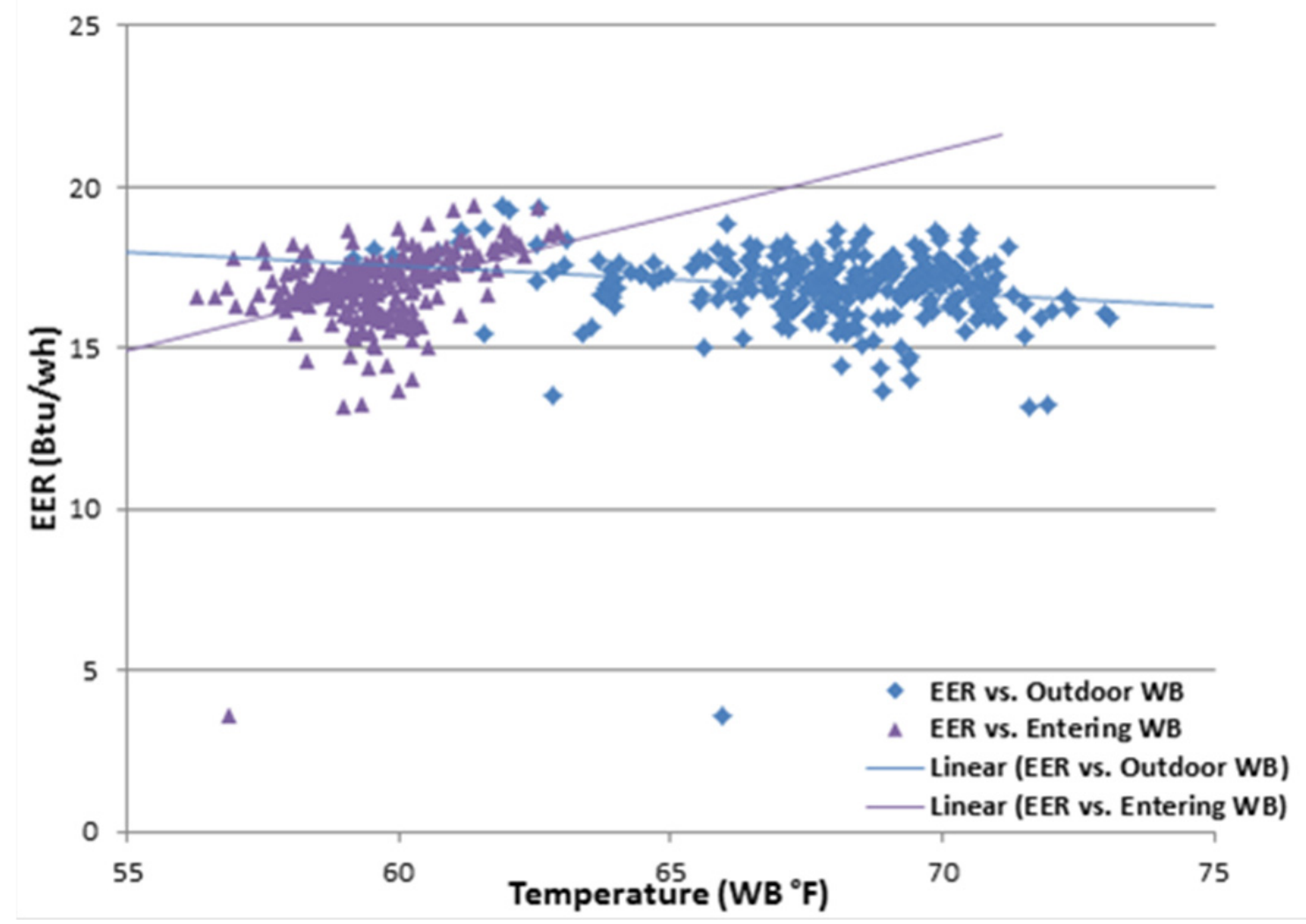

Figure 7: Full load condenser EER (Btu/wh) (no indoor fan energy) versus both outdoor and entering wet-bulb temperatures $\left(\mathrm{WB}^{\circ} \mathrm{F}\right)$ 


\section{Section 3: Measure Implementation Details}

\subsection{Field Inspection}

All installation work must follow local and national code. Installers should familiarize themselves with their local jurisdiction and identify any requirements that may be specific to the project. Special attention should be paid whenever retrofit work is to be conducted as existing homes may pose unique safety concerns.

\section{¿CAUTION - Installing and servicing air conditioning systems can be hazardous!}

- Technicians with proper training are necessary. Licensed HVAC professionals should hold appropriate contractor and refrigerant handling licenses.

- Always make sure there is an electrical disconnect installed with all outdoor condensers and turn off the electrical disconnect before installing or servicing air conditioning equipment. There may exist more than one disconnect.

- Wear appropriate protective clothing and gear including safety glasses and gloves.

- All equipment used for refrigerant charging, evacuation, and charge measurements should be certified and properly maintained. Follow EPA guidelines for proper handling and disposal of refrigerant. Refrigerant venting is prohibited by law.

Evaporative condenser system installation criteria should be reviewed and compared to site conditions. A pre-installation inspection should determine the following information for the equipment under consideration:

- Are there local water use limitations on evaporative cooling systems that may preclude use of the system?

- Is there adequate access to supply water at the proposed location for the condensing unit?

- What are the local requirements for disposing of purged water? Is there adequate capability for purge water drainage at the proposed location for the condensing unit?

- For retrofits, is the proposed equipment compatible with existing systems, specifically the evaporator coil and refrigerant type? If not, the scope of work may be greater than replacing the condensing unit only. 


\subsection{System Design and Site Preparation Sizing an Air Conditioner}

Accurately estimating the cooling load on a home is important to select an appropriately sized air conditioner. Undersized units are unable to cool the house sufficiently and oversized units cycle excessively, reducing air conditioner efficiency, humidity control, and occupant comfort. Air conditioners should be sized and selected in accordance with ACCA Manuals J and S. The Manual J sizing procedure takes into account house characteristics including orientation, insulation levels, windows, and internal gains, as well as duct location and quality to estimate the cooling capacity and system airflow necessary on a "design" summer day. Manual S outlines a procedure for selecting an air conditioner based on manufacturer data and Manual J results.

For hot-dry climates, refer to EC manufacturer's engineering tables for rated capacities at design conditions. Because evaporative condensers maintain their capacity at higher design conditions, it may be possible to specify a smaller capacity EC than a standard air-cooled condensing unit, especially in severe cooling climates like Phoenix or Las Vegas. In a retrofit situation, it may be possible to downsize the condensing unit by a half ton or more and still provide the same cooling capacity.

\section{Duct Design}

Proper sizing of the ductwork is also essential to ensure expected performance from any air conditioner. Undersized ducts create high pressure losses, resulting in reduced airflows and high fan energy use. ACCA Manual D duct sizing procedures should be followed to ensure correct duct sizing. In retrofit applications replacement or repair of the duct system may be warranted. The designer should try to minimize system pressure drop as much as possible by shortening duct runs, properly size return and supply ducts, avoid overly restrictive filters, and limiting duct bends and connections.

\section{TXV Selection}

When possible, all systems should be installed with a variable refrigerant metering device. Evaporative condensers tend to have a lower pressure difference between the high and low sides than do air-cooled systems. Most TXVs are not designed for such low pressure differentials. Subsequently, an oversized TXV should be used or one that is specifically designed for lowpressure applications. Check with the manufacturer for their recommendations.

\subsection{Installation Prodecure}

The following instructions outline the general installation steps that are specific for evaporative condensers and are not meant to be a step-by-step installation procedure. It is important to follow manufacturer-supplied installation instructions as requirements vary by product. Contractor training in the particular product being installed is highly recommended. Where information is omitted, refer to standard air-cooled residential condenser installation practices. Refer to Attachment A for a checklist to follow for installations.

\section{Important!}

Installation and servicing of air conditioning systems can be hazardous and technicians with proper training are necessary. Always turn off the electrical disconnect when servicing the unit.

Step 1 - Condenser location and installation: Identify an appropriate location prior to installation. The condenser must be located where there is access to electricity and water and with adequate 
capability to drain bleed or purge water. Condensing units should be properly located outdoors on a level concrete pad, preferably positioned to avoid direct sun. The installation should conform with minimum clearance requirements to ensure adequate condenser airflow and access to service panels. The concrete pad on which the condensing unit is installed must be level to ensure proper water distribution over the condenser coils. Always ensure there is an electrical disconnect which is disconnected whenever servicing or replacing a condensing unit.

Step 2 - Supply water: Connect the water supply to the water fitting on the condenser. While the supply water need not be from a potable source, this is the most straightforward solution in most instances. Always check with manufacturer's literature regarding use of non-potable water. Turn the water supply on and fill the water sump to the appropriate level by adjusting the float (Figure 8). The pump may need to be running to accurately set the float level. Water treatment is generally not necessary, since chlorine added to city water supplies along with the flushing cycle of the evaporative condenser are adequate as biocide treatment of water for residential applications. If chemical water treatment is used, check with manufacturer, local codes and water

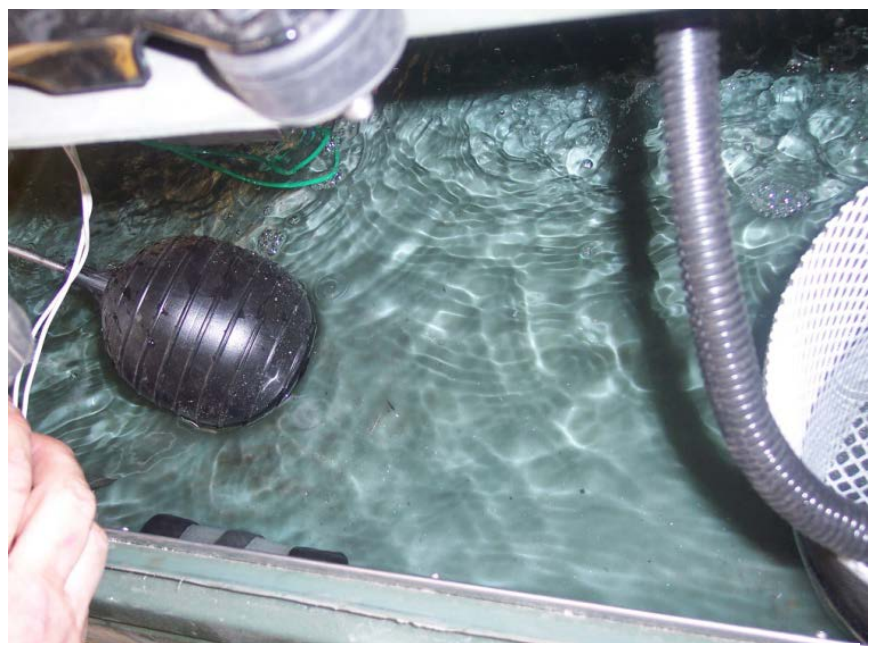

Figure 8: Float to adjust water sump level authorities for permissible products and requirements for proper disposal of chemical water treatments.

Step 3 - Purge water: Connect a hose to the drain line and route to the desired location. Drain water must be routed away from the condensing unit and the house foundation to minimize erosion but is safe to be used for a number of purposes including landscaping. Check local requirements because in hard water areas some landscaping may not tolerate the higher salt and mineral content of the purge water. The line may be directed to vegetation nearby or captured in a reservoir for use elsewhere. Units with a continuous bleed strategy utilize gravity to expel the water from the sump. These systems require that the drain hose lie lower than the elevation of the condenser for the system to function correctly. Units with a purge pump provide more flexibility in options for disposing of the purge water. If chemical water treatment is used, the purge line may need to be routed to an appropriate drain.

If the unit has a purge control, adjust it based on local conditions. Preferably, water hardness and alkalinity is measured onsite; otherwise, local or regional water reports may be referenced. Refer to manufacturer specifications for setting based on water quality. 
Step 4 - Evacuation and Charging: Refer to manufacturer's installation instructions for refrigerant line evacuation and charging procedures. All work must be performed by licensed and trained personnel with proper equipment. Follow the current EPA guidelines for refrigerant handling. Federal law prohibits refrigerant venting. For systems with a TXV installed at the indoor coil, refrigerant charging must be accomplished using the sub-cooling method according to sub-cooling targets provided by the manufacturer. Follow best practices regarding under what outdoor conditions charging should be conducted.

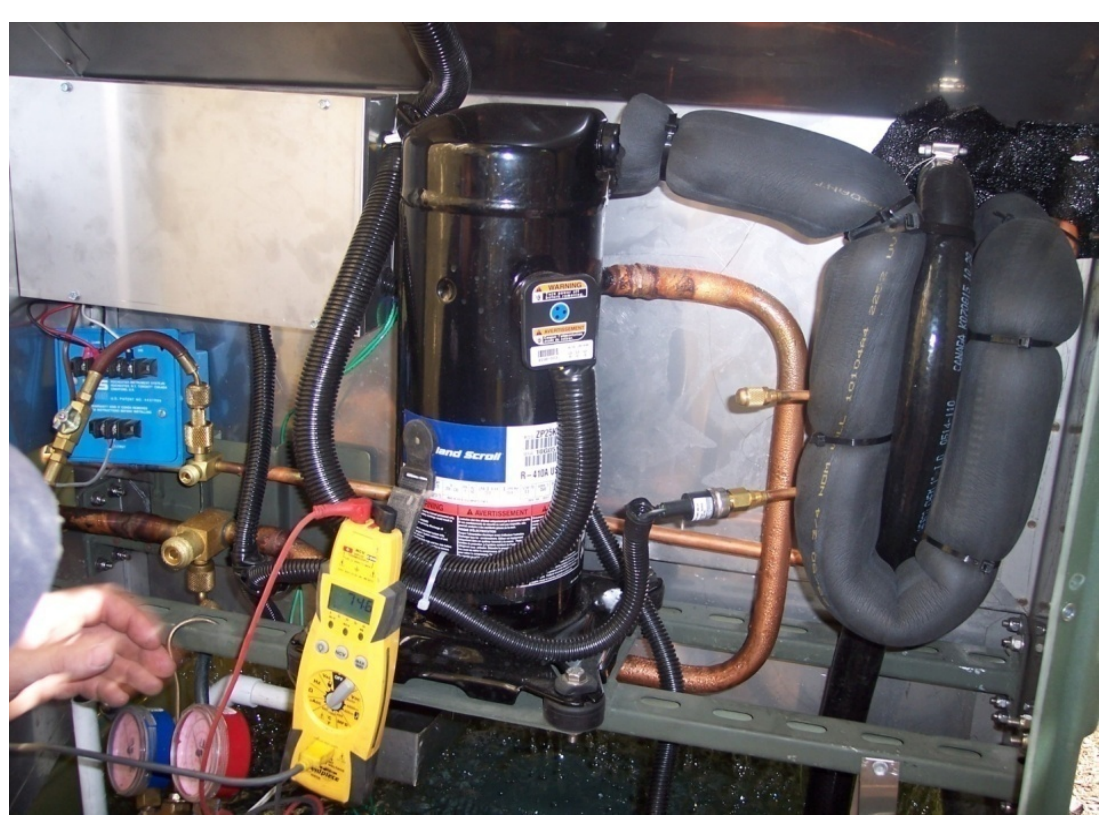

Figure 9: Gauges connected to operating evaporative condenser to verify correct charge

\subsection{Verification Procedures and Tests}

\section{System Start-up}

Once installation is complete, the manufacturer start-up procedures should be followed and the system tested for correct operation. Before starting the system, verify the following:

- All panels and doors are in place and secure

- The sump drain cap is in place and secure

- The water supply valve is turned on and the sump is filled to the required level

- A clean air filter is installed upstream of the indoor fan

- The electrical disconnect is in the ON position.

At the indoor thermostat turn the system into cooling mode and lower the temperature setpoint to initiate air conditioner operation. Verify that the following systems are functioning correctly:

- Indoor fan is supplying air to the supply registers and exhausting from the return

- Outdoor compressor turns on

- Water circulation system: verify the water is circulating from the sump to the spray nozzles and that the spray nozzles are emitting a continuous spray and are not clogged.

- Water sump level; verify that the float switch and fill valve are both functioning and that the level in the sump is at the desired level and remaining constant.

- Water bleed or purge system: with bleed systems verify that bleed is continuous and there doesn't appear to be any restrictions in the line. With periodic purge systems operate the 
system long enough to verify that the purge pump activates and purges the sump to the required level. Ensure the purge level is set appropriately. For all systems, make sure water is being bled or purged to the proper location.

\section{System Commissioning}

System commissioning is an important component of any installation to ensure that the system operates per design expectations. This is especially true in retrofit applications where improper existing conditions may negate the benefits from implementation of this measure. Recommended tests include the following (while some of these tests do not specifically address the condensing units they are imperative to achieve optimal unit capacities and efficiencies.):

- Cooling coil airflow: It is recommended that airflow be tested preferably using an airflow metering plate or fan assisted duct blaster, although a good flow hood will suffice. Due to system restrictions imposed by the ductwork and other components, relying on the tap setting specifications is not an accurate way of verifying correct airflow. A minimum of $350 \mathrm{cfm}$ per installed ton of capacity is recommended. In dry climates, where the need for latent cooling is minimal, higher airflow (up to $500 \mathrm{cfm}$ per ton) is desirable. In humid climates where the latent component of cooling is more pronounced, lower airflows are suggested, around $350 \mathrm{cfm} / \mathrm{ton}$.

- Fan watt draw: Ductwork restrictions can result in both reduced airflow and increased fan energy use. AHRI rating procedures assume an optimistic fan efficacy of $0.365 \mathrm{~W} / \mathrm{cfm}$. However, field studies have shown that fans can use as much as $1.2 \mathrm{~W} / \mathrm{cfm}$. Verify that fan power is equal to or less than $0.58 \mathrm{~W} / \mathrm{cfm}^{8}$.

- Duct leakage testing: Duct leakage can represent a significant portion of energy use for space conditioning and reduces cooling system performance. Verify that duct leakage to outdoors in new ductwork is less than $4 \mathrm{cfm}$ at 25 Pascals per 100 square feet of conditioned floor area or $6 \%$ of total system airflow, whichever is lower. For existing ducts diagnose and repair leaks to the extent possible. The goal is to minimize duct leakage as much as possible; attempts should be made to reduce leakage to at least $15 \%$ of total system airflow. In some cases, replacement of the duct system may be warranted.

\section{Third-party Testing}

Third-party testing is always recommended to verify correct installation and ensure expected performance. Recommended tests include verification of refrigerant charge, cooling coil airflow, fan watt draw, and duct leakage.

\subsection{Operation and Maintenance}

Evaporative condensers require semi-annual maintenance at the beginning and the end of each cooling season. In addition, standard maintenance practices associated with air-cooled systems should also be followed including regular air filter replacement, cleaning of condenser coils, etc.

\section{Bi-annual Start-up:}

1. Remove the front door and clear the sump area of debris. Wash it out with water.

\footnotetext{
${ }^{8}$ California's Title-24 energy code includes a prescriptive requirement for system fan power of $0.58 \mathrm{~W} / \mathrm{cfm}$ based on field results from California research in new construction homes.
} 
2. If present, inspect the sacrificial anode(s) to determine if replacement is necessary. If there is heavy mineral deposits on the sump floor, consult the manufacturer regarding alternative methods for water treatment.

3. Remove and clean the circulation pump intake screen. Replace the screen when clean. (Figure 10)

4. Rinse out sump of debris and minerals as needed.

5. Ensure the drain cap is in place and secure.

6. Remove and clean the screen at the water supply valve. Replace the screen when clean.

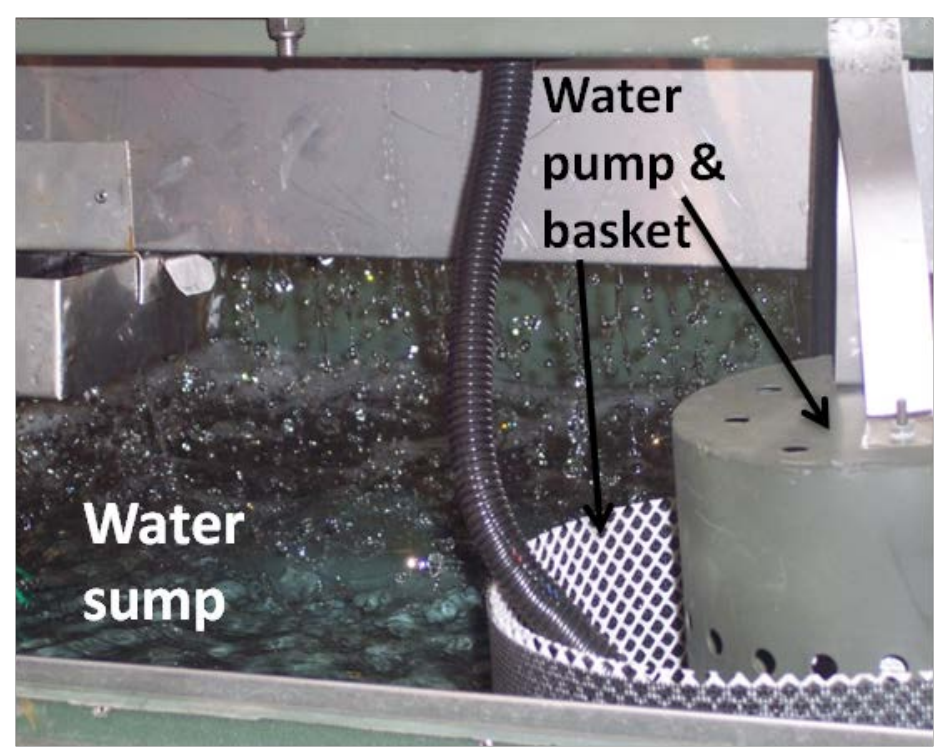

Figure 10: Water sump and pump filter basket during operation

7. Turn on the water valve and fill the sump to the appropriate level according to manufacturer instructions. Verify that the float is adjusted properly.

8. Remove the top access panel and inspect the condenser coils and spray nozzles. If excessive mineral deposits are visible, cleaning may be necessary. Follow manufacturerspecific details for cleaning as improper handling of the condenser coils may invalidate the warranty.

9. Clean access doors and panels as appropriate if coated with mineral deposits

10. Turn the electrical disconnect to the on position.

11. At the indoor thermostat turn the temperature setpoint down to initiate air conditioner operation.

12. Confirm that the outdoor compressor and pump are operating and that water is circulating correctly.

13. Replace and secure the front door and any other panels that were removed.

\section{Bi-annual Shut-down:}

1. Turn off the thermostat, electrical disconnect and the supply water valve.

2. Remove the drain cap and drain the sump entirely. Rinse off intake screens, flush the sump pan and pump screens.

3. Once sump is empty, leave the drain cap removed so that the sump drains through winter. Store drain cap in a safe place for use the following summer.

4. Replace and secure any panels that may have been removed. 


\section{Attachment A: Prescriptive Measure Checklist for Contractors}

\section{Installation Procedure Guidelines for Evaporative Condensers}

\section{Completed?}

\section{Field Inspection}

1.1 Is the proposed equipment compatible with existing or planned mechanical systems?

1.2 Is there adequate access to supply water at the proposed location for the condenser?

1.3 Is there capability for purge water drainage at the proposed location for the condenser?

\section{System Design}

2.1 Condenser sizing

2.1.1 Manual J and S completed Cooling Load:_ A/C Size:

2.2 Ductwork design

2.2.1 Manual D completed

\section{Installation}

3.1 Unit location

3.1.1 Unit is level for proper water distribution over the condenser coils

3.2 Supply water

3.2.1 Water supply connected to the fitting at the unit

3.2.2 Sump filled to the proper level and water supply valve turned on

3.2.3 Float level is set appropriately

3.2.4 If required, water treatment system properly installed or applied

3.2.4 Drain cap in place and secure

\subsection{Purge water}

3.3.1 Hose properly routed to drain location

3.3.2 Purge control adjusted and set

3.4 Evacuation and charging

3.4.1 System was completely evacuated before initiating charge

3.4.2 Proper charge has been set and verified

3.5 Electrical connections at the condenser

3.5.1 Communication between condenser and thermostat

3.5.2 Electrical disconnect installed

3.6 Clean air filter installed upstream of the indoor fan

\section{Verification and Operation}

4.1 Visual verification of correct operation

4.1.1 System responds properly to user input to thermostat

4.1.2 Water circulation system functions correctly and spray nozzles aren't clogged

4.1.3 Water sump level is correct and self-maintains and the fill valve functions correctly

4.1.4 Water purge functions correctly

4.2 System airflow tested Airflow (cfm):

4.3 System fan power on maximum cooling Power (W):

4.3 Duct leakage Leakage $(\mathrm{cfm}): \quad$ Leakage (\% of airflow):

4.3 O\&M manual provided to occupant - Maintenance service contract should be set up with the installer or the occupant made familiar of all maintenance procedures. 


\section{Attachment B: Modeling Methodology and Detail}

BEopt modeling evaluated both new construction and existing homes in a variety of climates. The new construction model was based on a standard 2,400 $\mathrm{ft}^{2} \mathrm{~B} 10$ Benchmark house which was assumed to be square, with equal wall area and equal window area on all four cardinal orientations. Construction assumptions are based on the House Simulation Protocols (HSP) (NREL, 2010) and the insulation and window values were tailored to each climate zone. The foundation was assumed to be slab for all climate zones.

Table 7: New Construction Assumptions by Climate Zone

\begin{tabular}{c|c|c|c|c|c}
\hline BA Climate Zone & Hot-Dry & $\begin{array}{c}\text { Hot- } \\
\text { Humid }\end{array}$ & $\begin{array}{c}\text { Mixed- } \\
\text { Humid }\end{array}$ & Marine & Cold \\
\hline \hline IECC Climate Zone & CZ 3B & CZ 2A & CZ 2A & CZ 3C & CZ 5B \\
\hline Representative City & $\begin{array}{c}\text { Sacramento, } \\
\text { CA }\end{array}$ & $\begin{array}{c}\text { Houston, } \\
\text { TX }\end{array}$ & $\begin{array}{c}\text { Atlanta, } \\
\text { GA }\end{array}$ & $\begin{array}{c}\text { Santa } \\
\text { Rosa, CA }\end{array}$ & $\begin{array}{c}\text { Denver, } \\
\text { CO }\end{array}$ \\
\hline Wall Insulation & R-13 & R-13 & R-13 & R-13 & R-13+R-5 \\
\hline Window U-value/SHGC & $0.4 / 0.3$ & $0.4 / 0.3$ & $0.4 / 0.3$ & $0.4 / 0.3$ & $0.35 / 0.35$ \\
\hline $\begin{array}{c}\text { Slab Insulation R-Value } \\
\text { and Depth }\end{array}$ & R-0 & R-0 & R-0 & R-0 & $10,2 \mathrm{ft}$ \\
\hline Ceiling Insulation & R-30 & R-30 & R-30 & R-30 & $\mathrm{R}-38$ \\
\hline
\end{tabular}

For existing homes, building geometry and configuration were determined based on research and review of the 2010 DOE Buildings Energy Data Book (BEDB) (DOE, 2011) and the 2009 California Residential Appliance Saturation Study (RASS) (KEMA, 2010) and include the following:

- Single story 1,800 square foot home with three bedrooms. This is consistent with RASS and BEDB averages. RASS average for single family homes is $1,882 \mathrm{ft}^{2}$ for California building stock. BEDB estimates characteristics of a typical single-family home from the mid 1970s with a heated average floor space of 1,934sqft and a cooled average floor space of $1,495 \mathrm{ft}^{2}$. Average conditioned floor area of homes constructed between 1980 and 1989 is $1,806 \mathrm{ft}^{2}$.

- $16 \%$ glass as a percentage of conditioned floor area, based on RASS averages. The BEDB reports window areas for a typical 1970 s era home of between $11 \%$ and $15 \%$ of conditioned floor area.

- Glass is equally distributed on all four sides to eliminate orientation effects

- Wall area and slab perimeter based on an aspect ratio of 2.0. This is consistent with a sampling of actual homes. To maintain equal wall and glazing areas distribution on all orientations, an L-shape building model was used.

Three eras of existing homes were evaluated according to the distinctions made in the HSP (pre 1980, 1980s era, and 1990s era). Building characteristic assumptions are based on the HSP as well as California's Title 24 vintage assumptions where appropriate. U-factor and SHGC values 
for the single metal-pane windows were taken from the default values in Tables 116-A and 116B in California's 2008 Building Energy Efficiency Standards (CEC, 2010).

Table 8: Existing Home Assumptions by Building Vintage

\begin{tabular}{c|c|c|c}
\hline & Pre 1980 & $\mathbf{1 9 8 0 - 1 9 8 9}$ & Post 1989 \\
\hline \hline Wall Insulation & $\mathrm{R}-0$ & $\mathrm{R}-11$ & $\mathrm{R}-13$ \\
\hline Window U-value/SHGC & $\begin{array}{c}\text { Single metal } \\
1.28 / 0.80\end{array}$ & $\begin{array}{c}\text { Single metal } \\
1.28 / 0.80\end{array}$ & $\begin{array}{c}\text { Single metal } \\
1.28 / 0.80\end{array}$ \\
\hline $\begin{array}{c}\text { Slab Insulation R-Value } \\
\text { and Depth }\end{array}$ & $\mathrm{R}-0$ & $\mathrm{R}-0$ & $\mathrm{R}-0$ \\
\hline Ceilling Insulation & $\mathrm{R}-0$ & $\mathrm{R}-9$ & $\mathrm{R}-13$ \\
\hline
\end{tabular}

The furnace and water heater are assumed to have been seldom or never maintained. Base efficiency specifications and Maintenance Factors (MFs) were taken from Table 30 and Table 33 in the HSP. The furnace was assumed to have a rated efficiency of 78 AFUE and the water heater $0.54 \mathrm{EF}$. Equations 19 and 21 in the HSP were used to degrade the efficiency according to age and MF. Ductwork was assumed to be located in the attic with R-2.1 insulation and 30\% leakage.

Appliance, lighting, and plug energy end-uses are all based on Building America assumptions. Appliances are assumed to be standard efficiency and five years old. 10\% fluorescent lighting is assumed for existing homes. 


\section{Attachment C: Additional Modeling Results}

Table 9 and Table 10 show the cooling energy savings for an existing home that was built between 1980 and 1989 for the SEER 13 and SEER 15 base cases, respectively.

Table 9: Annual Cooling Energy Savings Compared to an Existing Home Circa 1980 with a SEER 13 Air Conditioner

\begin{tabular}{|c|c|c|c|c|c|c|c|c|c|}
\hline \multirow{2}{*}{$\begin{array}{c}\text { Building } \\
\text { America } \\
\text { Climate Zone }\end{array}$} & \multirow{2}{*}{$\begin{array}{c}\text { IECC } \\
\text { Climate } \\
\text { Zone }\end{array}$} & \multirow{2}{*}{ Sample City } & \multicolumn{2}{|c|}{$\begin{array}{c}\text { Annual Cooling } \\
\text { Energy Use (kWh) }\end{array}$} & \multirow{2}{*}{$\begin{array}{l}\text { Annual } \\
\text { kWh } \\
\text { Savings }\end{array}$} & \multirow{2}{*}{$\begin{array}{c}\% \\
\text { kWh } \\
\text { Savings }\end{array}$} & \multirow{2}{*}{$\begin{array}{l}\text { Annual } \\
\text { kW } \\
\text { Savings }\end{array}$} & \multirow{2}{*}{$\begin{array}{c}\% \\
\mathbf{k W} \\
\text { Savings }\end{array}$} & \multirow{2}{*}{$\begin{array}{c}\text { Annual } \\
\text { Utility } \\
\text { Savings } 9\end{array}$} \\
\hline & & & $\begin{array}{l}\text { Base } \\
\text { Case }\end{array}$ & $\begin{array}{c}\text { Evap } \\
\text { Condenser }\end{array}$ & & & & & \\
\hline Hot-Dry & $3 \mathrm{~B}$ & Fresno, CA & 5,534 & 4,120 & 1,414 & $26 \%$ & 1.94 & $30 \%$ & $\$ 159$ \\
\hline Hot-Humid & $2 \mathrm{~A}$ & Houston, TX & 6,409 & 5,478 & 931 & $15 \%$ & 1.51 & $24 \%$ & $\$ 105$ \\
\hline Mixed-Humid & $2 \mathrm{~A}$ & Atlanta, GA & 4,004 & 3,380 & 624 & $16 \%$ & 1.41 & $23 \%$ & $\$ 70$ \\
\hline Cold & $5 \mathrm{~B}$ & Denver, CO & 2,073 & 1,515 & 558 & $27 \%$ & 2.08 & $34 \%$ & $\$ 63$ \\
\hline
\end{tabular}

Table 10: Annual Cooling Energy Savings Compared to an Existing Home Circa 1980 with a SEER 15 Air Conditioner

\begin{tabular}{|c|c|c|c|c|c|c|c|c|c|}
\hline \multirow{2}{*}{$\begin{array}{c}\text { Building } \\
\text { America } \\
\text { Climate Zone }\end{array}$} & \multirow{2}{*}{$\begin{array}{c}\text { IECC } \\
\text { Climate } \\
\text { Zone }\end{array}$} & \multirow{2}{*}{ Sample City } & \multicolumn{2}{|c|}{$\begin{array}{c}\text { Annual Cooling } \\
\text { Energy Use (kWh) }\end{array}$} & \multirow{2}{*}{$\begin{array}{c}\text { Annual } \\
\text { kWh } \\
\text { Savings }\end{array}$} & \multirow{2}{*}{$\begin{array}{c}\% \\
\text { kWh } \\
\text { Savings }\end{array}$} & \multirow{2}{*}{$\begin{array}{c}\text { Annual } \\
\text { kW } \\
\text { Savings }\end{array}$} & \multirow{2}{*}{$\begin{array}{c}\% \\
k W \\
\text { Savings }\end{array}$} & \multirow{2}{*}{$\begin{array}{c}\text { Annual } \\
\text { Utility } \\
\text { Savings } \\
10\end{array}$} \\
\hline & & & $\begin{array}{l}\text { Base } \\
\text { Case }\end{array}$ & $\begin{array}{c}\text { Evap } \\
\text { Condenser }\end{array}$ & & & & & \\
\hline Hot-Dry & $3 \mathrm{~B}$ & Fresno, CA & 4,924 & 4,120 & 804 & $16 \%$ & 1.29 & $22 \%$ & $\$ 90$ \\
\hline Hot-Humid & $2 \mathrm{~A}$ & Houston, TX & 5,705 & 5,478 & 227 & $4 \%$ & 0.88 & $15 \%$ & $\$ 26$ \\
\hline Mixed-Humid & $2 \mathrm{~A}$ & Atlanta, GA & 3,563 & 3,380 & 183 & $5 \%$ & 0.81 & $15 \%$ & $\$ 21$ \\
\hline Cold & $5 B$ & Denver, CO & 1,839 & 1,515 & 325 & $18 \%$ & 1.45 & $26 \%$ & $\$ 37$ \\
\hline
\end{tabular}

Annual cost for water usage was calculated for each climate zone based on seasonal ton-hours of cooling output from BEopt modeling and an average consumption rate of 2.5 gallons per ton-hr based on prior studies of both field and laboratory testing (DEG, 2008; Keesee et al, 2010; SCE, 2009). Water consumption rates will vary based on local climate conditions. A national average water rate of $\$ 3.90$ per 1,000 gallons was used (Global Water Intelligence, 2009). Results are shown in Table 11.

\footnotetext{
9 National average utility rate of $\$ 0.1126 / \mathrm{kWh}$

${ }^{10}$ National average utility rate of $\$ 0.1126 / \mathrm{kWh}$
} 
Table 11: Annual Water Operating Costs for Evaporative Condenser Assuming National Average Water Rates

\begin{tabular}{c|c}
\hline Climate Zone & $\begin{array}{c}\text { Annual } \\
\text { Water Costs }\end{array}$ \\
\hline Hot-Dry & $\$ 22$ \\
Hot-Humid & $\$ 34$ \\
Mixed-Humid & $\$ 18$ \\
Marine & $\$ 1$ \\
Cold & $\$ 5$ \\
\hline
\end{tabular}

Table 12 and Table 13 show the incremental cost over the SEER 13 and SEER 15 base cases, respectively, that would result in a positive annual cash flow to the homeowner based on estimated utility electricity savings, increased water costs, and mortgage payments. The assumptions are the same as in the similar analysis based on electricity savings only (Table 3 and Table 4) and include a 30-year mortgage term.

Table 12: Incremental Cost Justified by Energy Modeling Savings Compared to a SEER 13 Air Conditioner for Various Interest Rate Financing Scenarios - Includes Both Energy Utility Savings and Additional Water Costs

\begin{tabular}{c|c|c|c|c|c|}
\hline Climate Zone & $\mathbf{3 \%}$ & $\mathbf{4 \%}$ & $\mathbf{5 \%}$ & $\mathbf{6 \%}$ & $\mathbf{7 \%}$ \\
\hline Hot-Dry & $\$ 1,007$ & $\$ 889$ & $\$ 791$ & $\$ 708$ & $\$ 638$ \\
\hline Hot-Humid & $\$ 559$ & $\$ 494$ & $\$ 439$ & $\$ 393$ & $\$ 354$ \\
\hline Mixed-Humid & $\$ 294$ & $\$ 260$ & $\$ 231$ & $\$ 207$ & $\$ 186$ \\
\hline Marine & $\$ 21$ & $\$ 19$ & $\$ 17$ & $\$ 15$ & $\$ 13$ \\
\hline Cold & $\$ 190$ & $\$ 167$ & $\$ 149$ & $\$ 133$ & $\$ 120$ \\
\hline
\end{tabular}

Table 13: Incremental Cost Justified by Energy Modeling Savings Compared to a SEER 15 Air Conditioner for Various Interest Rate Financing Scenarios - Includes Both Energy Utility Savings and Additional Water Costs

\begin{tabular}{c|c|c|c|c|c}
\hline Climate Zone & $\mathbf{3 \%}$ & $\mathbf{4 \%}$ & $\mathbf{5 \%}$ & $\mathbf{6 \%}$ & $\mathbf{7 \%}$ \\
\hline Hot-Dry & $\$ 387$ & $\$ 342$ & $\$ 304$ & $\$ 272$ & $\$ 246$ \\
Hot-Humid & $\$ 0$ & $\$ 0$ & $\$ 0$ & $\$ 0$ & $\$ 0$ \\
Mixed-Humid & $\$ 0$ & $\$ 0$ & $\$ 0$ & $\$ 0$ & $\$ 0$ \\
Marine & $\$ 1$ & $\$ 1$ & $\$ 1$ & $\$ 1$ & $\$ 1$ \\
Cold & $\$ 65$ & $\$ 58$ & $\$ 51$ & $\$ 46$ & $\$ 41$ \\
\hline
\end{tabular}




\section{References}

ACCA. Manual D Residential Duct Systems. Air Conditioning Contractors of America.

ACCA. Manual J Residential Load Calculations, Eighth Edition. Air Conditioning Contractors of America.

ACCA. Manual S Residential Equipment Selection. Air Conditioning Contractors of America.

ARBI (2011). “Test Plan: Evaporative Condenser Performance.” Prepared for Building America by the Alliance for Residential Building Innovation (ARBI). August, 2011.

CARB (2009). “2009 Annual Progress Report Budget Period 2 (BP2) - Attachment BB: Second Generation Evaporative Condenser Summary Report." Prepared for the Department of Energy by The Consortium for Advanced Residential Buildings. December, 2009.

CEC (2010). "2008 Building Energy Efficiency Standards - Residential Compliance Manual.” California Energy Commission, CEC-400-2008-016-CMF-Rev1. July, 2010.

DEG (1998). "Evaluation of Residential Evaporative Condensers in PG\&E Service Territory." Davis Energy Group. December, 1998.

DEG (2008). "Evaluation of the Freus Residential Evaporative Condenser System in PG\&E Service Territory." Prepared for Pacific Gas and Electric Company. Application Assessment Report \# 0605. March 13, 2008.

DEG (2010). “Zero Net Energy Program Technology Assessment Report: Evaporative Condenser Technology Assessment.” Davis Energy Group. Prepared for Pacific Gas and Electric Company. December, 2010.

DOE (2011). “2010 Buildings Energy Data Book.” Prepared by D\&R International, Ltd. under contract with Pacific Northwest National Laboratory. March, 2011.

Global Water Intelligence, (2009). "No let up in pressure on water tariffs." Vol 10, Issue 9. September, 2009. http://www.globalwaterintel.com/archive/10/9/market-insight/no-let-pressurewater-tariffs.html.

Hendron, R.; Engebrecht, C. (2010). Building America House Simulation Protocols. Golden, CO: National Renewable Energy Laboratory. NREL/TP-550-49246.

KEMA (2010). "2009 Residential Appliance Saturation Study (RASS).” KEMA. Prepared for the California Energy Commission, CEC \#200-2010-004. October, 2010.

Keesee, M.; Bisbee, D. (2010). “The AquaChill.” Sacramento, CA: Energy Efficiency, Customer Research \& Development, Sacramento Municipal Utility District (SMUD). March 12, 2010 . 
SCE (2009). "Performance Evaluation of an Evaporatively-Cooled Split-System Air Conditioner." Design and Engineering Services, Southern California Edison. November 20, 2009.

Springer, D.; Eastment, M.; Dakin, W.; Rainer, L. (2008). "Comparative Performance of Four Prototype Mechanical Systems in a Desert Climate.” ASHRAE Paper \#SL-08-061. June, 2008. 


\section{U.S. DEPARTMENT OF Energy Efficiency \& ENERC Renewable Energy}

